\title{
Lilianna DORAK-WOJAKOWSKA
}

Akademia Ignatianum w Krakowie

lilianna.d@interia.pl

\section{RELACJE POMIĘDZY KULTURA \\ A ETNICZNOŚCIĄ W TEKSTACH \\ CEZARII ANNY BAUDOUIN \\ DE COURTENAY-EHRENKREUTZ- \\ -JĘDRZEJEWICZOWEJ}

ABSTRACT Relations between Culture end Ethnicity in the Texts of Cezaria Anna Baudouin de Courtenay-Ehrenkreutz-Jędrzejewiczowa

The article describes main fields of interest of the outstanding Polish ethnologist, one of the most important researchers of folk rituals and culture in the interwar period. The article analyses her texts dedicated to ethnical and national problems, in which there are deliberations on the research subject of ethnology (whose distinguishing criterion is tradition) and its scientific material, which serve the cognition of culture's morphology. Research on products of folk culture, mostly from Wileńszczyzna, passed in oral tradition, makes possible such cognition. Interrelationship between ethnicity and culture is present in crucial texts of Cezaria Baudouin de Courtenay-Ehrenkreutz-Jędrzejewiczowa collected in the volume The Tradition's Chain written in the years 1922-1953, such as: 'From Studies of Wedding Rites of Polish People' (1929), 'A Few Notes and News about Ethnography of Wileński District' (1930), 'Two Cultures and Two Sciences' (1936) and 'Ethnical Groups on the Territory of the Great Duchy of Lithuania and Three Nations' (1953). Using the phenomenological method in the research of folk culture on the borderland between Poland and Lithuania, Cezaria Jędrzejewiczowa interprets preserved stories, tracks down their main motifs, reveals their genesis and meaning, which has developed over centuries. The article discusses social and cultural determinants of the rural people, such as ties of tradition, ethnical collective consciousness, religion and language. 
Słowa kluczowe: kultura ludowa, obrzęd, naród, etniczność, tradycja

Keywords: folk culture, ritual, nation, ethnicity, tradition

1.

Problematyka etniczna zyskuje coraz większe zainteresowanie wśród badaczy kultury, czego wyrazem są międzynarodowe konferencje, powstające w wielu krajach grupy specjalistów oraz liczne czasopisma wyspecjalizowane w tematyce etniczności lub - jak przyjęło się określać - antropologii etniczności (anthropology of ethnicity) ${ }^{1}$. Największą popularnością problematyka etniczna cieszyła się dotychczas u historyków i socjologów. Pierwsi koncentrowali się głównie na dziejach formowania się narodu, rekonstrukcji stosunków międzyetnicznych, migracjach i przesiedleniach, zmieniających etniczne granice i mapy, oraz na historii mniejszości narodowych i ich roli w procesach dziejowych. Drudzy skupiali uwagę na teoretycznych kwestiach związanych ze statusem badanych jednostek etnicznych i charakterem procesów ich transformacji, a także śledzili bieżący rozwój sytuacji etnicznej, poświęcając sporo miejsca problemowi tożsamości, uprzedzeń, stereotypów, konfliktów oraz procesom integracji i asymilacji².

W wyniku zmiany paradygmatów obowiązujących do niedawna w obrębie współczesnych nauk o człowieku i jego kulturze, preferujących studia nad tradycyjnymi formami kultur „ludowych” czy „pierwotnych”, uwaga badaczy skierowała się na nowe procesy i środowiska społeczno-kulturowe, w tym również na problemy etniczne, rozpoczynając od studiów nad małymi grupami etnicznymi, a na dociekaniach nad procesami narodowotwórczymi i formowaniem się ponadnarodowych wspólnot cywilizacyjnych kończąc ${ }^{3}$. Kulturowy wymiar interpretacji stosowany przez etnologów stał się wkrótce szczególnie atrakcyjnym narzędziem uprawiania etnologii, a także zyskał uznanie w obrębie wielu innych dyscyplin, w tym kulturoznawstwa, które spostrzegły, że jednym z ważniejszych wymiarów tych dociekań jest świat symboli, wartości, mitów, wyobrażeń, czyli mentalna warstwa kultury, generująca wszelkie idee etniczne, decydujące w dużej mierze o kształcie stosunków międzygrupowych i przebiegu procesów etnicznych.

Byłoby jednak dużym uproszczeniem twierdzić, że związki pomiędzy kulturą a etnicznością zacieśniać się zaczęły stosunkowo niedawno. Jak pisze Aleksander Posern-Zieliński: Siegraja one daleko w przesztość i można je śledzić co najmniej od czasów J.G. Herdera, kiedy to romantyczne zainteresowania kultura $i$,duchem"ludu (Volksgeist)

1 A. Posern-Zieliński, III. Problematyka etniczna w badaniach etnologicznych i antropologicznych. Studia etniczne w polskiej etnologii po 1945 roku. Ich uwarunkowania, konteksty i nurty, „Lud” 1995, t. 78, s. 294.

2 Zob.: tamże, s. 293.

3 Zob.: tami̇e, s. 294. 
zaczęty sie splatać z ideologią nacjonalistyczna, z ruchami patriotycznymi, a także z fascynacją nad wielokulturowością szeregu rejonów Europy ${ }^{4}$.

W Polsce początki badań etnicznych w obrębie etnologii sięgają okresu międzywojennego. Powstanie niepodległego państwa polskiego, a wraz z nim ponowna reintegracja narodowa w sposób naturalny kierowała uwagę badaczy na rodzimą kulturę ludową i wartości wiejskiej tradycji dla odbudowy nowej tożsamości. Jednak odrodzona Rzeczpospolita okazała się w tym czasie państwem zamieszkałym przez liczne mniejszości narodowe i etniczne (szczególnie na jej wschodnich i zachodnich rubieżach) konstytuujące blisko jedną trzecią całej populacji krajus ${ }^{5}$ Z drugiej strony problematyka etnograficznego opisu grup etnicznych zamieszkujących obszary kresowe należała od początków kształtowania się dyscypliny do tych zagadnień, które cieszyły się znacznym powodzeniem.

Prowadzone $\mathrm{w}$ dwudziestoleciu międzywojennym badania etnograficzne można podzielić na dwie podstawowe orientacje. Pierwsza z nich, tradycyjna, koncentrowała się na etnograficznych opisach poszczególnych grup etnicznych lub też na kulturowej charakterystyce tych regionów, które zamieszkiwane były przez ludność niepolskiego pochodzenia. Problematyka ta poszerzana była o próby wytyczania granic etnicznych w oparciu o zasięg etnograficznych artefaktów, o dociekania nad etnogenezą Polaków i sąsiednich ludów słowiańskich. Do badaczy reprezentujących tę orientację należą m.in. Kazimierz Moszyński i Kazimierz Dobrowolski (z wczesnego okresu twór-

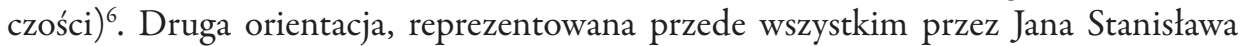
Bystronia i Józefa Obrębskiego ${ }^{7}$, upatrywała istotę badań etnograficznych w dążeniu do uchwycenia elementów świadomości grupowej, które decydują o poczuciu odrębności, określają tożsamość, wyznaczają granice obcości, cementują wspólnotę, a także w badaniu stosunków międzyetnicznych (konflikty, antagonizmy, wzajemne zależności), gdyż tylko poprzez nie ujawnia się złożona sieć wzajemnych powiązań.

$\mathrm{Na}$ przykład według Bystronia przedmiotem badań etnograficznych powinny być „treści kulturowe” będące własnością określonych grup społecznych, a nie same grupy. Grupa etniczna jest jednym z pojęć, którym etnografowie i etnolodzy wciąż operują. Jest to zarazem jedno z pojęć najmniej ścisłych. W wypadkach idealnych grupa etniczna to grupa ludzka nacechowana przez posiadanie kilku podstawowych cech. Po pierwsze, odrębnego języka lub co najmniej silnie wyróżniającej się gwary. Po drugie, poczucia pewnej bliskości łączącej jej członków, któremu jako jego negatyw odpowiada poczucie obcości w stosunku do analogicznych grup innych. Po trzecie, odrębnej

Tamże, s. 295. Por.: L. Dégh, The Study of Ethnicity in Modern European Ethnology, [w:] Folklore, Nationalism and Politics, red. F.J. Oinas, Columbus 1978, s. 34, Indiana University Folklore Institute Monograph Series.

5 Szerzej na ten temat zob.: A. Posern-Zieliński, Ksztattowanie się polskiej etnografii jako samodzielnej dyscypliny naukowej (do 1939), [w:] Historia etnografii polskiej, red. M. Terlecka, Wrocław 1973, s. 90, Historia Nauk Spotecznych i Humanistycznych w Polsce; tenże, III. Problematyka etniczna..., s. 297.

6 Więcej na ten temat zob.: Historia etnografii polskiej, s. 185-189.

Zob.: J. Obrębski, Problem grupetnicznych wetnologii ijego socjologiczne ujęcie, „Przegląd Socjologiczny” 1936, t. 4, s. 177-195; tenże, Problem etniczny Polesia, „Sprawy Narodowościowe” 1936, R. 10, nr 1-2. 
nazwy w ustach własnych lub co najmniej w ustach grup sąsiednich czy geograficznie pobliskich. I wreszcie po czwarte, mniej albo bardziej swoistej kultury. W konkretnych przypadkach najczęściej występują tylko niektóre z tych cech. Muszą jednak występować po dwie, trzy razem, abyśmy mogli daną grupę nazwać etniczną, a nie po prostu językową, względnie gwarową albo kulturową lub czysto geograficzną. Jest oczywiste, że każda grupa etniczna składa się m.in. z fizycznego (rasowego) podłoża. Każda grupa etniczna jest w oczach etnologa czy etnografa psychiczno-kulturową formacją, istniejącą dzięki kontynuującemu się ciągle, choć ewoluującemu realizowaniu się psychiczno-kulturowych wzorców, przechodzących z pokolenia na pokolenie. W badaniach etnograficznych kultura, język i psychika człowieka stanowią nierozerwalną całość. W przeciwieństwie do etnologii, która zajmuje się badaniami porównawczymi nad poszczególnymi wytworami i całymi działami kultury tzw. niższej, nieograniczającymi się do jakichś poszczególnych, zwłaszcza niewielkich grup etnicznych czy mniejszych obszarów geograficznych - etnografia wychodzi od grup etnicznych ${ }^{8}$.

Pomimo założenia, że etnografia nie jest nauką o grupach społecznych, Bystroń uważał, że studium „kultury ludowej” musi poprzedzać studium „terytorium etnograficznego". Przed przystąpieniem do badań poszczególnych działów kultury trzeba zapoznać się z grupami, które zamieszkują badane terytorium i podtrzymują kulturę?".

Dziś w etnologii, podobnie jak w innych naukach społecznych, zauważalna jest rozbieżność stanowisk wobec ujmowania badanych zjawisk w określone kategorie i terminologii stosowanej do ich opisu. Na przykład część badaczy (m.in. Sławoj Szynkiewicz, Andrzej Sadowski) ${ }^{10}$ operuje szeroko rozumianym terminem „grupa etniczna”, któ-

$8 \quad$ Przymiotnik ethnikos jak wiele innych terminów naukowych jest pochodzenia greckiego. Stowo ethnos oznaczato zbiorowiska (grupy), których istnienie stwierdzano, obserwujac je, względnie przeciwstawiając sobie. $Z$ czasem coraz wyraźniej zarysowuje się określenie ob cy ch, innych ludów wyrazem ethnos, przeciwstawianych swemu lu do wi, czy też narodowi. Na przyktad kluby sportowe w Atenach starożytnych, do których nie należeli Ateńczycy, nazywaty się klubami „etnicznymi”, ethnikoi. [...] $W$ Dziejach Apostolskich stowo ethnos stosuje się do pogan, w odróżnieniu ich od Żydów - Judejczyków. [...] Przymiotnik ethnikos (etniczny), wędrując w ciagu wieków przemian myśli politycznej i badawczej, nie stracit również najbardziej istotnego sktadnika swej treści. [...] Na przyktad w greckim tekście Ewangelii sw. Mateusza (5.47) przymiotnik „etniczny” stosuje się do zwyczajów innych, obcych, pogańskich, nie zaś wtasnych-żydowskich - C. Baudouin de Courtenay-Ehrenkreutz-Jędrzejewiczowa, 2. Grupa etniczna, [w:] taż, Łańcuch tradycji. Teksty wybrane, wybór L. Mróz, A. Zadrożyńska, Warszawa 2005, s. 384-386, Archiwum Etnologiczne. Zob. też: K. Moszyński, Cztowiek. Wstęp do etnografii powszechnej i etnologii, Wrocław 1958, s. 3.

9 Zob.: J.S. Bystroń, Wstęp do ludoznawstwa polskiego, Lwów 1926, s. 33-35, Lwowska Biblioteka Slawistyczna, 1. W tym miejscu należy zaznaczyć, iż Bystroń korzystał z wyników badań etnograficznych przeprowadzonych w ciągu ponad pięćdziesięciu lat i niektóre z wyróżnionych przez dawnych badaczy grupy, które znalazły się na jego mapie, już w czasach międzywojennych nie istniały lub istnienie ich w ogóle było podawane w wątpliwość. Por.: B. Kopczyńska-Jaworska, Problem świadomości etnicznej i narodowej. Metody i osiagnięcia badań polskiej etnografii, „Lud” 1983, t. 67, s. 158.

10 Do ważniejszych opracowań poświęconych zagadnieniu grup etnicznych należą: S. Szynkiewicz, Silva ethnicum, [w:] Konflikty etniczne. Źródta, typy, sposoby rozstrzygania, red. I. Kabzińska-Stawarz, S. Szynkiewicz, Warszawa 1996, s. 319-334, Biblioteka Etnografii Polskiej, 51; A. Sadowski, Narody wielkie i mate - Biatorusini $w$ Polsce, Kraków 1991; tenże, Pogranicze polsko-biatoruskie. Tożsamość mieszkańców, Białystok 1995. 
ry obejmuje zarówno zbiorowości plemienne, grupy etnograficzne, grupy etniczne w wąskim rozumieniu (niebędące narodami, wyróżniane przez badaczy na podstawie obiektywnych cech kulturowych), jak i grupy o statusie narodu. W tym ujęciu można postawić znak równości między grupą etniczną i narodem. Operowanie szeroko rozumianym pojęciem grupy etnicznej pozwala na porównywanie w ramach jednej kategorii typologicznej różnych zbiorowości, np. Litwinów, Białorusinów mieszkających na terenie Polski. Jak zauważa Iwona Kabzińska: Należatoby dodać, że efektem stosowania szeroko rozumianego terminu "grupa etniczna" powinna być rezygnacja z takich pojęćjak: "tożsamość narodowa” (i zastąpienie jej „tożsamościa etnicznq"), „mniejszość narodowa” (powinno sie ja zastąić „mniejszościa etniczna”) ${ }^{11}$. W literaturze przedmiotu zauważalny jest jednak brak tego typu konsekwencji. Część badaczy (m.in. Zbigniew Jasiewicz i Grzegorz Babiński) ${ }^{12}$ pozostaje przy rozróżnieniu grupy etnicznej - w węższym rozumieniu - i narodu ${ }^{13}$. Najczęściej grupa etniczna wyróżniana jest na podstawie nazwy, uczestnictwa w kulturze postrzeganej jako odmienna od innych, zamieszkiwania na określonym terytorium (etnicznym), wiary we wspólnotę pochodzenia i świadomości własnej odrębności ${ }^{14}$. Według Fredrika Bartha odrębność etniczna jest wyznaczana przez granice o charakterze symbolicznym, kulturowym ${ }^{15}$.

Obecnie kategoria „etniczności” zyskuje zastosowanie w badaniach kulturoznawczych. Odnosi się ona do kulturowych praktyk i zapatrywań danej społeczności ludzkiej, odróżniających ją od innych społeczności. Istotne z punktu widzenia relacji pomiędzy etnicznością a kulturą jest współwystępowanie konkretnych praktyk kulturowych, czyli zwyczajów, obrzędów, a także wytworów kultury, w tym języka, wraz ze świadomością własnej kulturowej odmienności. Na ten aspekt w swoich badaniach etnograficznych zwróciła uwagę Cezaria Anna Baudouin de Courtenay-Ehrenkreutz-Jędrzejewiczowa, przeprowadzając formalną analizę zależności pomiędzy kulturą ludową a etnicznością na terytorium dawnej Rzeczpospolitej. Nikt bodaj wcześniej w polskich badaniach etnograficznych nie posunął się tak daleko, jak to uczyniła polska badaczka, której doświadczenie i wyobraźnia antropologiczna doprowadziły w wędrówce za pytaniem o prapolskie praktyki kulturowe do analiz świadectw historycznych dotyczących zwyczajów i obrzędów jako pozostałości dawnych rytuałów i wierzeń. Podkreślając, jak doniosłe znaczenie dla polskiej nauki o przed-

I. Kabzińska, Między grupa etniczną a narodem, „Etnografia Polska” 2000, t. 44, z. 1-2, s. 52.

12 Zob.: Z. Jasiewicz, Tatarzy polscy. Grupa etniczna czy etnograficzna?, „Lud” 1980, t. 64, s. 145-157; tenże, Polacy z Ukrainy w Kazachstanie. Etniczność i historia, „Lud” 1992, t. 75, s. 11-54. Zob. też: G. Babiński, Pogranicze polsko-ukraińskie. Etniczność, zróżnicowanie religijne, tożsamość, Kraków 1997.

13 Zob.: I. Kabzińska, Między grupa etniczna..., s. 52.

14 Zob.: M.S. Szczepański, Region pogranicza kulturowego w perspektywie socjologicznej. Przypadek Górnego Ślaska, [w:] Kultury regionalne ipogranicza kulturowe a świadomośc etniczna, red. I. Bukowska-Floreńska, Katowice 1999, s. 161-180, Prace Naukowe Uniwersytetu Śląsiego w Katowicach, 1749. Studia Etnologiczne i Antropologiczne, 2; E. Michna, Eemkowie. Grupa etniczna czy naród?, Kraków 1995, s. 15, Religiologica Juventa.

15 Zob.: I. Kabzińska, Między grupa etniczną..., s. 52. Por.: F. Barth, Introducion, [w:] Ethnic Groups and Boundaries. The Social Organisation of Cultural Difference, red. tenże, Boston 1969. 
stawieniach kulturowych mają prace uczonej, chciałabym zaznaczyć wagę i miejsce aspektów przedstawieniowych opisywanych przez nią praktyk. Szczególnie ważne będzie przybliżenie roli, jaką odgrywają język, zwyczaje, obrzędy weselne i wierzenia w życiu wspólnotowym ludności wiejskiej.

Warto zatem przyjrzeć się bliżej zwłaszcza tym jej tekstom, w których kategoria etniczności jako element ustanawiający relacje międzyludzkie stanowi istotne kryterium opisu i wyodrębniania omawianych przez nią zjawisk kultury.

2.

Cezaria Anna Baudouin de Courtenay-Ehrenkreutz-Jędrzejewiczowa urodziła się 2 sierpnia 1885 r. w Dorparcie (obecnie Tartu, Estonia) jako najstarsze dziecko Romualdy z Bagnickich iJana Baudouin de Courtenay ${ }^{16}$. Matka była absolwentką petersburskich Wyższych Kursów dla Kobiet, tzw. bestużewskich (wyższej uczelni dla kobiet założonej przez Konstantyna Bestużewa-Riumina). Jan Baudouin de Courtenay, zwany ojcem językoznawstwa polskiego, wykładał wówczas na Uniwersytecie w Dorparcie. W 1893 r. objął Katedrę Językoznawstwa Porównawczego i Sanskrytu na UJ, co pociągnęło za sobą przeprowadzkę rodziny do Krakowa. Tu też był jednym z najaktywniejszych członków powstałego w 1898 r. oddziału Towarzystwa Ludoznawczego. W Krakowie po kilku latach nauki domowej Cezaria Baudouin de Courtenay w 1889 r. w wieku trzynastu lat została przyjęta do piątej klasy klasycznego gimnazjum żeńskiego w Krakowie ${ }^{17}$. I choć do krakowskiego gimnazjum uczęszczała tylko dwa lata, to jednak ten okres krakowski wywarł przemożny wpływ na jej formację i przyszłe losy. Świadczą o tym jej słowa napisane w 1909 r. w liście do koleżanki Anieli Gruszeckiej, późniejszej żony prof. Kazimierza Nitscha, mówiące o tym, iż właśnie wtedy, w atmosferze Krakowa, wybrała dla siebie drogę naukową ${ }^{18}$.

Szeroka społeczna działalność obojga rodziców ${ }^{19}$, a także jawnie głoszone przez profesora demokratyczne i laickie poglądy wywoływały opór konserwatywnego śro-

16 Jan Baudouin de Courtenay z Romualdą z Bagnickich miał pięcioro dzieci: Cezarię Annę (1885-1967), Zofię Janinę (1887-1967) - malarkę, Świętosława Teofila (1889-1960) - prawnika, Ewelinę Petronelę (1892-1985) - rusycystkę (po mężu Małachowska-Łempicka), Marię Helenę (1897-1945) - prawniczkę (po mężu Kierbant-Wiśniewska). Zob.: J. Róziewicz, Powiąanie Jana Niecistawa Baudouin z petersburskim ośrodkiem naukowym, [w:] Dziatalność naukowa, dydaktyczna i spoteczno-polityczna Jana Niecistawa Baudouina de Courtenay w Rosji, red. tenże, Wrocław 1991, s. 95.

17 Szerzej na ten temat zob.: Byta taka szkota. Gimnazjum im. Elizy Orzeszkowej w Wilnie, 1915-1939, red. E. Sławińska-Zokościelna, Londyn 1987, s. 89.

18 D. Zamojska, Cezaria Baudouin de Courtenay-Ehrenkreutz-Jędrzejewiczowa, [w:] Kobieta i kultura. Kobiety wśród twórców kultury intelektualnej i artystycznej w dobie rozbiorów i w niepodlegtym państwie polskim. Zbiór studiów, t. 4, red. A. Żarnowska, A. Szwarc, Warszawa 1996, s. 161-162.

19 Romualda z Bagnickich w czasie pobytu z rodziną w Krakowie aktywnie działała m.in. w Towarzystwie Szkoły Ludowej, w Stowarzyszeniu Pomocy Naukowej dla Kobiet im. Józefa Ignacego Kraszewskiego (wspierającym studiujące na zagranicznych uniwersytetach Polki), w Czytelni dla Kobiet i w Towarzystwie Szkoły Gimnazjalnej Żeńskiej (którym Kraków zawdzięczał otwarcie w 1896 r. 
dowiska Krakowa. Stąd też rodzina Baudouinów de Courtenay opuściła to miasto i przeniosła się do Petersburga. W tamtejszym Uniwersytecie w 1900 r. profesor objął Katedrę Gramatyki Porównawczej i Sanskrytu ${ }^{20}$. Cezaria kontynuowała naukę w gimnazjum petersburskim, gdzie w 1903 r. uzyskała maturę. Studia podjęła na Wyższych Kursach dla Kobiet (tzw. bestużewskich) ${ }^{21}$, ale już w 1906 r., korzystając z otwarcia dla kobiet bram Uniwersytetu Petersburskiego, zapisała się na Wydział Historyczno-Filologiczny. Studiowała wówczas lingwistykę pod kierunkiem swego ojca, a także Aleksieja Szachmatowa ${ }^{22}$, Michaiła Rostowcewa ${ }^{23}$ i Tadeusza Zielińnskiego ${ }^{24}$. Jako jedna z pierwszych kobiet uzyskała dyplom I stopnia Petersburskiego Cesarskiego Uniwersytetu na podstawie rozprawy pt. Jezyk modlitewnika maryjnego, wieku XVI wydanego przez prof. Ptaszyckiego, napisanej pod kierunkiem prof. Tadeusza Zielińskiego ${ }^{25}$. W roku 1910 Cezaria Baudouin de Courtenay wyszła za mąż za Maxa Vasmera $^{26}$, ucznia jej ojca i kolegę ze studiów. Pomimo łączących ich wspólnych zainteresowań etnologicznych po trzech latach, po odbytej wyprawie badawczej do Grecji, małżeństwo to skończyło się rozwodem, a Cezaria przeniosła się do Warszawy, opuszczając rodziców i Petersburg ${ }^{27}$.

Od 1913 r. Cezaria Baudouin de Courtenay uczyła języka polskiego, rosyjskiego i łaciny w Warszawie w prywatnych polskich gimnazjach: Sabiny Tegazzo-Chmielewskiej, Zofii Sierpińskiej i Marii Tołwińskiej. Jednocześnie brała udział w pracach kulturalno-społecznych, a także w tajnych organizacjach niepodległościowych, gdzie poznała przyszłego męża Stefana Ehrenkreutza (1880-1945), profesora Wolnej Wszechnicy Polskiej i Uniwersytetu Warszawskiego oraz działacza PPS (do 1914)² ${ }^{28}$ z którym w 1916 r. wzię-

pierwszej szkoły średniej o profilu klasycznym dla dziewcząt, umożliwiającej absolwentkom uzyskanie matury, a tym samym prawa wstępu na austriackie wyższe uczelnie). W tym właśnie gimnazjum w 1898 r. rozpoczęła naukę Cezaria Baudouin de Courtenay. Zob.: C. Baudouin de Courtenay-Ehrenkreutz-Jędrzejewiczowa, Eańcuch tradycji..., s. 10. i Oswiecenia Publicznego, j.3142). Natomiast świadectwo pracy przechowywane w APAN (III-298, j.31) podaje datę 27 V 1911 r. Por. C. Baudouin de Courtenay-Ehrenkreutz-Jędrzejewiczowa, Eańcuch tradycji..., s. 11.

26 Max Vasmer (1886-1962) - niemiecki slawista, językoznawca i etnolog; profesor uniwersytetów w Lipsku i Berlinie.

27 Zob.: D. Zamojska, Cezaria..., s. 163.

Zob.: J. Róziewicz, Powiązanie..., s. 96.

Archiwum Polskiej Akademii Nauk w Warszawie (APAN), Materiały Rodziny Baudouin de Courenay, sygn. III-298, k. 2.

Aleksiej A. Szachmatow (1864-1920) - rosyjski językoznawca i historyk kultury; profesor Uniwersytetu w Petersburgu, uważany za twórcę rosyjskiej tekstologii.

Michaił I. Rostowcew (1870-1952) - rosyjski historyk i archeolog, profesor uniwersytetów w Petersburgu i Yale (od 1920 r.), publikował także pod nazwiskiem M.I. Rostovtzeff.

adeusz Zieliński (1859-1944) - filolog klasyczny i filozof, profesor uniwersytetów w Petersburgu Warszawie; autor prac z dziedziny kultury antycznej.
Tamże, s. 164-165. 
ła ślub ${ }^{29}$. Wypełniając obowiązki zawodowe i wychowując trójkę dzieci, kontynuowała badania naukowe z zakresu etnografii i wierzeń hagiograficznych. W 1921 r. Cezaria Baudouin de Courtenay-Ehrenkreutz przeniosła się z rodziną do Wilna, gdzie prof. Stefan Ehrenkreutz objął Katedrę Dawnego Polskiego i Litewskiego Prawa Sądowego na Uniwersytecie im. Stefana Batorego. Cezaria uczyła wówczas języka łacińskiego w gimnazjum im. Elizy Orzeszkowej w Wilnie, podjęła także starania o przyznanie jej habilitacji na podstawie rozprawy z zakresu etnologii pt. Święta Cecylia - przyczynek do genezy apokryfów, którą uzyskała na Uniwersytecie Warszawskim w 1922 r. ${ }^{30}$ Po przeniesieniu habilitacji na Uniwersytet Wileński podjęła tam w 1924 r. wykłady jako docent. Ostatecznie karierę uniwersytecką otwarła dla niej decyzja Ministerstwa Wyznań Religijnych i Oświecenia Publicznego z 17 sierpnia 1927 r., na mocy której objęła stanowisko profesora w Katedrze Etnografii i Etnologii Uniwersytetu im. Stefana Batorego w Wilnie ${ }^{31}$. W latach 1924-1927 jako docent na tym uniwersytecie prowadziła wykłady z etnografii i etnologii. W tym samym czasie prowadziła również lekcje w Państwowym Gimnazjum Żeńskim jako etatowa nauczycielka. W 1929 r. mianowana została profesorem nadzwyczajnym etnologii i etnografii na Wydziale Humanistycznym Uniwersytetu im. Stefana Batorego. Na bazie swoich badań nad kulturą ludową Wileńszczyzny założyła przy Uniwersytecie Muzeum Etnograficzne ${ }^{32}$.

Zwrot zarówno w stosunkach rodzinnych, jak i naukowych prof. Cezarii Baudouin de Courtenay-Ehrenkreutz nastąpił dopiero w 1933 r. Wówczas to rozeszły się drogi jej i jej męża, profesor zmieniła wyznanie na ewangelickie, wyszła ponownie za mąż,

29 Małżeństwo to zaowocowało trojgiem dzieci: w 1917 r. przyszła na świat Krystyna (zm. 1927), w 1919 r. Tadeusz (zm. 1976) i w 1921 r. Andrzej, niegdyś profesor orientalistyki w Ann Arbor (Michigan, USA), dziś mieszka w Australii. Por.: C. Baudouin de Courtenay-Ehrenkreutz-Jędrzejewiczowa, Eańcuch tradycji..., s. 11.

30 Szerzej na ten temat zob.: J. Draus, Życie i dziatalność Cezarii Baudouin de Courtenay-Ehrenkreutz-Jędrzejewiczowej (1885-1967), [w:] Losy Polek żyjących na obczyźnie i ich wktad w kulturę i naukę świata - bistoria i wspótczesność. Materiaty z IV Sympozjum Biografistyki Polonijnej-Wiedeń 1-2 września 1999, red. A. Judycka, Z. Judycki, Lublin 1999, s. 50.

31 Pod dwóch latach postanowieniem prezydenta Rzeczpospolitej Polskiej z 19 XI 1929 r. mianowana została profesorem nadzwyczajnym etnologii i etnografii na Wydziale Humanistycznym Uniwersytetu Wileńskiego. APAN, Materiały Cezarii Baudouin de Courtenay-Ehrenkreutz-Jędrzejewiczowej, sygn. $31, \mathrm{k} .48$.

32 Muzeum Etnograficzne ( $z$ dziatem archeologicznym) zaktadu etnologii Uniwersytetu Stefana Batorego $w$ Wilnie (Wydziat Humanistyczny) powstato 4 marca 1925 roku w celu zagospodarowania przedmiotów zebranych przez zaktad na ziemiach pótnocno-wschodnich Rzeczypospolitej, zwtaszcza w czasie prac nad jeziorami trockimi. Gromadzito także rękopisy i dokumentacje ikonograficzna oraz przedmioty i artefakty archeologiczne. Kierownikiem muzeum byta prof. Cezaria Baudouin de Courtenay-Ehrenkreutzowa - równocześnie kierowniczka zaktadu etnologii. Po niej p.o. kierownika zostat prof. Erwin Koschmieder (1934/35), a następnie kierownikiem wybrano prof. Kazimierza Moszyńskiego. Asystentką przy muzeum byta Maria Znamierowska-Prüfferowa. Placówka znajdowata się przy ul. Zamkowej 11. Kres jej istnieniu przyniosty wydarzenia II Wojny Światowej. Nie wiemy, co się stato ze zbiorami - W. Pastuszka, Muzeum Etnograficzne Uniwersytetu Stefana Batorego w Wilnie. Prośba o pomoc, Archeowieści, 5 III 2013, [online] http://archeowiesci.pl/2013/03/05/muzeum-etnograficzne-uniwersytetu-stefana-batorego-w-wilnie-prosba-o-pomoc/, 19 IX 2014. 
tym razem za Janusza Jędrzejewicza ${ }^{33}$, opuściła Wilno, przenosząc się na Uniwersytet Warszawski, gdzie 25 stycznia 1934 r. mianowana została profesorem zwyczajnym nowo utworzonej Katedry Etnografii Polskiej ${ }^{34}$. Na okres warszawski przypada jej udział w założeniu Muzeum Etnograficznego, opublikowanie dwóch ważnych prac: Dwie kultury i dwie nauki oraz Folk Dances and Wedding customs (1936), oraz działalność społeczna m.in. w Związku Pracy Obywatelskiej Kobiet.

Po wybuchu wojny wraz z mężem wyemigrowała z kraju. Najpierw przebywała w Rumunii ${ }^{35}$, a następnie, kiedy to w 1940 r. otworzyły się możliwości ewakuacji części polskich uchodźców cywilnych, Jędrzejewiczowie udali się do Palestyny. Od 1942 r. Cezaria Jędrzejewiczowa otrzymywała stypendium z Funduszu Kultury Narodowej w Londynie, kierowanego przez doc. Jana Hulewicza, i prowadziła badania wschodnioznawcze z zakresu historii, etnografii i archeologii w ramach działalności sekcji orientalistycznej Biura Studiów Bliskiego i Środkowego Wchodu z siedzibą w Jerozolimie ${ }^{36}$. Zadaniem tej placówki badawczej było przygotowanie warsztatu naukowego do budowy orientalistyki w powojennej Polsce. Pokłosiem tych badań było wydanie prac: Wskazówki dla zbierajacych przedmioty dla muzeów i archiwów etnograficznych w Polsce (1944); Święty Jerzy patronem harcerstwa (1944); Kalendarz świętojerski lub zbadany w Bazylice św. Grobu w Jerozolimie; Święty Jerzy - studium kulturologiczne; Antonina Czarniecka, pątniczka z Zamojszczyzny; Huculski Bereza i rumuńska Brezeia na tle zwyczajów Bożego Narodzenia (1944).

W 1945 r., po ewakuacji części uchodźców polskich z Iranu do Libanu i powołaniu w Bejrucie Polskiego Instytutu Studiów Bliskiego Wschodu, przekształconego wkrótce w Instytut Polski w Bejrucie, prof. Jędrzejewiczowa odwiedziła Bejrut i na jezuickim Uniwersytecie św. Józefa wygłosiła dwa wykłady: „Deux espects de St. Georges” i „Metoda fenomenologiczna - współczesna etnografia i etnologia”. Współpraca ta nie trwała długo, gdyż w 1947 r. Polski Humanistyczny Instytut Naukowy w Jerozolimie na skutek ewakuacji polskich uchodźców do Wielkiej Brytanii zakończył działalność37. Podczas gdy w okresie palestyńskim (1943-1947) prof. Jędrzejewiczowa uczestniczyła w życiu społecznym polskich uchodźców, na okres londyński przypada jej mocne

33 Janusz Jędrzejewicz (1885-1951) - w latach 1931-1934 minister wyznań religijnych i oświecenia publicznego, autor reformy szkolnictwa, a w latach 1933-1934 premier rządu polskiego.

34 Szerzej na ten temat okresu warszawskiego, wojny i okupacji oraz okresu powojennego (na emigracji w Londynie) w życiu i działalności Cezarii Baudouin de Courtenay-Ehrenkreutz-Jędrzejewiczowej zob.: J. Draus, Życie i dziatalność...; L. Turkowski, Prof. dr Cezaria Baudouin Courtenay-Ehrenkreutz-Jędrzejewiczowa. Wspomnienie, „Lud” 1968, t. 52, s. 357-360. Zob też: Etnografowie i ludoznawcy polscy. Sylwetki, szkice biograficzne, t. 1, red. E. Fryś-Pietraszkowa, A. Kowalska-Lewicka, A. Spiss, Kraków 2002, s. 3-7.

35 Zob.: T. Dubicki, Polscy uchodźcy w Rumunii 1939-1945. Studia i materiaty, Warszawa 1995, s. 84.

36 Zob.: J. Draus, R. Terlecki, Polskie szkoty wyższe i instytucje naukowe na emigracji 1939-1945, Wrocław 1984, s. 23-24, Nauka dla Wszystkich, 382.

37 Zob.: J. Draus, Oświata i nauka polska na Bliskim i Środkowym Wschodzie 1939-1950, Lublin 1993, s. 77, Źródta i Monografie Towarzystwa Naukowego Katolickiego Uniwersytetu Lubelskiego, 124; T. Sulimirski, Fundusz Kultury Narodowej 1939-1946, „Nauka Polska na Obczyźnie” (Londyn) 1961, z. 3, s. 57. 
zaangażowanie się w życie polskiej emigracji. Była współzałożycielką Polskiej Rady Naukowej na Obczyźnie (powstałej w 1948 r.), która dwa lata później przekształciła się w Polskie Towarzystwo Naukowe na Obczyźnie. Często udzielała się na posiedzeniach naukowych Rady, jej referaty opublikowane zostały na łamach „Rocznika Polskiego Towarzystwa Naukowego na Obczyźnie”. Należała także do Zrzeszenia Profesorów i Docentów Polskich Szkół Akademickich na Obczyźnie (od 1948) oraz do grona naukowców związanych z Polskim Uniwersytetem na Obczyźnie (PUNO) ${ }^{38}$, w którym od 1958 r. do dnia swojej śmierci, czyli 28 lutego 1967 r., pełniła funkcję rektora.

Jej bogaty życiorys naukowy jest nieodłączną częścią historii nie tylko polskiej etnografii i etnologii. Należała do pokolenia odchodzących już i znikających z firmamentu wielkich profesorów, którzy odznaczają się nie tylko ogromną wiedzą w zakresie swej specjalności, ale przede wszystkim wielką kulturą ogólną. Byta petna osobistego czaru $i$ serdecznej dobroci, ożywiona twórczym zapatem i niespotykana życiowa energia. Do ostatnich chwil swego życia walczyta o wolnq naukę i kulture polską. W tym zakresie nie uznawata kompromisów ${ }^{39}$.

3.

Prac poświęconych tej wybitnej polskiej etnolog prawie wcale dotychczas nie pisano. Niewiele informacji dotyczących jej życia i rodziny zawarto w biogramach o charakterze encyklopedycznym ${ }^{40}$. Inne fakty z życiorysu prof. Cezarii Jędrzejewiczowej rozproszone są w kilku artykułach oraz w nie tak dawno wydanym zbiorze tekstów wybranych ${ }^{41}$. Przedmiotem tej części artykułu będzie analiza tekstów traktujących o kulturze i obrzędowości ludowej Wileńszczyzny, gdyż w tej właśnie dziedzinie uzyskała ona największe osiągnięcia.

Okres wileński, czyli lata 1925-1939, zajmuje szczególne miejsce w dorobku prof. Cezarii Baudouin de Courtenay-Ehrenkreutz-Jędrzejewiczowej. Odznacza się w jej działalności naukowej skupieniem środowiska naukowego katedry Uniwersytetu im. Stefana Batorego w Wilnie na badaniach terenowych, które zaowocowały stworzeniem w Wilnie prężnego ośrodka ludoznawczego, zorganizowaniem w 1925 r. wystawy tkanin ludowych, na bazie której prof. Jędrzejewiczowa założyła przy Uniwersytecie

38 Zob.: Z.A. Judycki, Polski Uniwersytet na Obczyźnie w Londynie. Stownik biograficzny pracowników naukowych, Londyn 2008, s. 14. Zob. także: Polski Uniwersytet na Obczyźnie w Londynie, [online] http://www.puno.edu.pl.

39 J. Gawenda, Jej życie to walka o wolnq naukę i kulturępolska, [w:] M. Ehrenkreutz-Jasińska, Romualda i Cezaria. Konkurs „Prababka w kolorze sepii”, „Twój Styl” 1993, nr 7/8, s. 57.

40 Zob.: A. Śródka, Uczeni polscy XIX-XX stulecia, t. 1: A-G, Warszawa 1994, s. 93; J. Draus, Życie i dziatalność..., s. 50; M. Jackiewicz, Nauka i uczeni na ziemi wileńskiej od XVI w. do 1945 r., Bydgoszcz 2010, s. 31, Biblioteka Wileńskich Rozmaitości. Seria B, 74. Encyklopedia Ziemi Wileńskiej, 9; D. Zamojska, Cezaria..., s. 161-162.

41 C. Baudouin de Courtenay-Ehrenkreutz-Jędrzejewiczowa, Eańcuch tradycji... Książka jest pierwszą pozycją z serii Archiwum Etnologiczne przygotowaną przez Instytut Etnologii i Antropologii Kulturowej Uniwersytetu Warszawskiego. 
Muzeum Etnograficzne, gromadząc zabytki regionu wileńskiego, oraz wielce znaczącymi z punktu widzenia etnologii i antropologii kultury tekstami: Wskazówki dla zbierajacych przedmioty dla Muzeum Etnograficznego Uniwersytetu Stefana Batorego w Wilnie (1926); Zwyczaje wiosenne ludu polskiego (1927); Ze studiów nad obrzędami weselnymi ludu polskiego, cz. 1: Forma dramatyczna obrzędowości weselnej (1929) oraz Kilka uwag i wiadomości o etnografii województwa wileńskiego $(1930)^{42}$, ujawniającymi fenomenologiczny nurt w etnografii polskiej ${ }^{43}$.

W swoich tekstach Cezaria Jędrzejewiczowa, korzystając z metody fenomenologicznej, przyjmuje sposób analizy pojęć i zjawisk stosowany w refleksji fenomenologicznej, która dotarła do Polski za pośrednictwem szkoły lwowskiej i Kazimierza Twardowskiego ${ }^{44}$, oraz analiz językoznawczych stosowanych przez ojca, wybitnego językoznawcę Jana Baudouin de Courtenay ${ }^{45}$. Stąd ważną rolę odgrywają w jej tekstach analizy językoznawcze. Postuluje ona przede wszystkim badania nad językami żywymi i dostępnymi obserwacji. Filozofia Twardowskiego i badania językoznawcze Jana Baudouin de Courtenay wiążą się z husserlowską postawą wobec zjawisk. Obejmują analizę aktów intencjonalnych realizowanych $\mathrm{w}$ trakcie historii jako wytwory kulturowe, szukają kształtowania się ich znaczenia, sensu poprzez idealną strukturę języka ${ }^{46}$.

W badaniach nad kulturą ludową pogranicza polsko-litewskiego Cezaria Jędrzejewiczowa odczytuje przetrwałe opowieści, tropi ich główne wątki, ukazuje ich genezę i kształtujący się przez wieki sens. We wczesnym tekście Święta Cecylia (1922) opisuje, jak funkcjonuje legenda o św. Cecylii w określonym środowisku, na określonym terenie, ukazuje wątki legendy w żaden sposób nienawiązujące do historycznej prawdy o życiu świętej. Istotny z punktu widzenia jej metody jest opis mający na celu uchwycenie wytworów kultury ludowej przekazywanej drogą tradycji ustnej. Oto jak uzasadnia wybór metody badawczej: Nie chodzi mi o prawdę h is to ry c z n a, ukryta w legendzie. „Prawda” jako fakt historyczny interesuje mnie tylko drugorzędnie. Natomiast na plan pierwszy wysuwa sie dążenie do odnalezienia tych nasion, z których wyróst „mit” [...] Ni eprawda bowiem świata realnego staje się nieraz w wyobraźni ludzkiejp ra w dą o napięciu o wiele silniejszym niż wszelkie prawdy niezbite i oczywiste, ale nie zaptadniajace twórczo fantazji ${ }^{4}$.

42 Teksty te zostały włączone do zbioru pism C. Baudouin de Courtenay-Ehrenkreutz-Jędrzejewiczowej Eańcuch tradycji...

43 Pełny spis bibliograficzny prac Cezarii Baudouin de Courtenay-Ehrenkreutz-Jędrzejewiczowej zob.: tamże, s. 403-405.

44 Kazimierz Twardowski (1866-1938) - filozof, profesor Uniwersytetu Lwowskiego; postulowal m.in. uprawianie filozofii jako teorii nauki. Zob.: A. Zadrożyńska, D. Zamojska, Przedmowa, [w:] C. Baudouin de Courtenay-Ehrenkreutz-Jędrzejewiczowa, Eańcuch tradycji..., s. 17.

45 Jan Niecisław Ignacy Baudouin de Courtenay (1845-1929) - polski językoznawca, uznawany za jednego z najwybitniejszych w historii dyscypliny. Jako pierwszy wprowadził rozróżnienie pomiędzy językiem - abstrakcyjnym zbiorem elementów, a mówieniem - realizacją owego systemu przez poszczególne jednostki.

46 Zob.: A. Zadrożyńska-Barącz, Fenomenologiczna koncepcja historii i kultury. Zastosowanie w polskich badaniach etnograficznych, „Etnografia Polska” 1968, t. 12, s. 21.

47 C. Baudouin de Courtenay-Ehrenkreutz-Jędrzejewiczowa, Święta Cecylia (przyczynek do genezy apokryfów), [w:] taż, Eańcuch tradycji..., s. 27-28. 
Zdaniem Jędrzejewiczowej materiał naukowy etnologii stanowią te wyktadniki twórczego stosunku spoteczeństw ludzkich do życia, które nazywamy wytworami kultury ${ }^{48}$. Cechy tych wytworów, takie jak czas, teren i środowisko, są materiałem naukowym jednocześnie dla wielu gałęzi nauki. Stąd też podstawowym kryterium wyboru przedmiotu badań jest w jej ujęciu tradycja. Jak pisze: Materiat naukowy etnologii odnajdujemy wśród zespotów ludzkich, żyjących w chwili, gdy dany wytwór dostaje się na pole obserwa$c j i^{49}$. [...] Każdy wytwór kultury, który należy do zakresu badań etnologicznych, jest tylko ostatnim ogniwem poprzedzajacego go szeregu form, przekazywanych przez tradycje, ostatnim wyktadnikiem tej tradycji. Nie sa nam znane formy go poprzedzające, jak również i jego pochodzenie na danym terytorium i $w$ danym spoteczeństwie $e^{50}$.

$\mathrm{Z}$ przytoczonych tu fragmentów tekstu wynika, że oddzielenie materiału naukowego od przedmiotu naukowego jest konsekwencją rozróżnienia zgodnego z zasadami fenomenologii, rozróżniania między przedmiotem i aktem postrzegania tego przedmiotu. Ostrożność, z jaką autorka traktuje wszystkie wcześniejsze formy wytworu zachowane w tradycji czy hipotezy na temat jego pochodzenia, są praktycznym zastosowaniem wskazań fenomenologów, by uznawać za prawdę tylko to, co w faktach jest oczywiste, a oczywiste jest to, na co wskazuje nasza intuicja. Właśnie w tradycji znajduje Jędrzejewiczowa wyobrażenie faktu jako efekt postrzegania faktu rzeczywistego przetworzonego za pomocą przeżycia ${ }^{51}$. Stąd zainteresowania polskiej etnolog skierowane początkowo ku starożytności helleńsko-bizantyjskiej i jej związkom ze Słowiańszczyzną stopniowo przeradzają się w zafascynowanie kulturą ludową i ludową obrzędowością, szczególnie wyróżniające w tej dziedzinie zjawisko, fenomen jako cechę znamienną, zarówno w odniesieniu do struktury, jak i funkcji kulturowej twórczości ludów ${ }^{52}$.

Nie chodzi jej w badaniu i analizie kultury ludowej o uchwycenie czynników historycznych czy socjologicznych działających w grupach ludzkich, które przejawiają się w wytworach kultury. Chodzi raczej o specjalny rodzaj typologii etnograficznej, uwzględniającej stosunki zachodzące między tworzywem, techniką wytwórczą, kształtem i funkcją ideologiczną przedmiotów, posiadające również swoją własną historię łańcucha przemian strukturalnych, własne dzieje tworzenia się typów, narastania nowych i ginięcia starych wartości. W badaniu form wytworów zróżnicowanych przede wszystkim przez teren, a nie przez czas tkwi jej zdaniem specyfika materiału naukowego etnologii. W swoich tekstach Jędrzejewiczowa stosuje się konsekwentnie do tych założeń.

Istotne miejsce w jej opisach etnograficznych zajmują tradycje ludowe województwa wileńskiego wzbogacone materiałem ilustracyjnym ${ }^{53}$. Na przykład w tekście zaty-

48 Tami̇e, s. 3.

49 Tamże, s. 4.

50 Tamże, s. 8.

51 Zob.: A. Zadrożyńska-Barącz, Fenomenologiczna koncepcja..., s. 23.

52 Szerzej na ten temat zob.: L. Turkowski, Prof. dr Cezaria..., s. 358.

53 Materiał ilustracyjny pochodzi głównie z Muzeum Etnograficznego Zakładu Etnologii Uniwersytetu Stefana Batorego, założonego w roku 1925. Został zebrany w latach 1925-1930, podobnie jak fotografie i rysunki. 
tułowanym Kilka uwag i wiadomości o etnografii województwa wileńskiego pisze, iż: [...] Kultura materialna województwa jest wyktadnikiem różnych nawarstwień historycznych, która dzięki konserwatyzmowi rolniczych warstw ludowych oraz warunkom życia (stan ekonomiczny kraju, środki komunikacyjne, stabo jeszcze rozwinięta siećszkolna) zachowata jeszcze cechy gdzie indziej należące już do przesztości ${ }^{54}$.

Kultura ta kształtowała się w wyniku ścierania się w ciągu wieków na tym terytorium wielu ludów i tradycji etnicznych - Polaków, Litwinów, Białorusinów, Żydów, Rosjan, Karaimów - przenikających się wzajemnie do dziś. Proces ścierania się i wzajemnego przenikania od wieków różnorodnych tradycji etnicznych (tradycji polskich, litewskich, białoruskich) na terenie województwa wileńskiego dotyczy zarówno dziejów struktury samych wytworów, jak i związanej z nimi terminologii. Jak to ujęła polska badaczka: [...] litewskq terminologię techniczna znaleźć można np. we wsiach mówiacych po polsku lub po biatorusku, i odwrotnie, stownictwo techniczne stowianskie we wsiach litewskich. $Z$ podobnymi przesunięciami spotykamy sięprzy tym w zakresie różnych kategorii wytworów, a więc np. zarówno form i terminów architektonicznych, jak i sprzętów i narzędzi gospodarskich, itp.

Do elementów wspólnych catemu obszarowi województwa należy zarówno rozplanowanie wnętrz domów mieszkalnych, jak i rozstawienie w nich sprzętów, a więc szczegóty drugorzędne w urzadzeniu domu ${ }^{55}$ (wyjątek stanowia tu pewne odchylenia, na zachodniej krawędzi Puszczy Rudnickiej spotykane, i tam także raczej jako formy uboczne i mniej rozpowszechnione $)^{56}$. To samo mniej więcej da siępowiedzieć i o nazwie przez Stowian na terenie województwa używanej: „chata”, jak i litewskim odpowiedniku „namas”. Nazwa pierwsza jest przy tym o wiele bardziej popularna, nie tylko ze względu na mate rozpowszechnienie jezyka litewskiego w województwie, lecz również ze względu na to, że termin "chata" (lit. cata) używany jest częściowo przez Litwinów, podczas gdy termin "namas" nie trafit do stownictwa biatoruskiego i polskiego ${ }^{57}$.

Przywoływane przez autorkę przykłady świadczą o przenikaniu się na terenach Wileńszczyzny w każdej dziedzinie życia różnych etnicznie kultur, zwłaszcza słownictwa, czego przykładem jest różnorodność terminologii służącej do określenia budynków i zabudowań wiejskich oraz ich wyposażenia, narzędzi pracy, sprzętów domowych i rzemiosła wiejskiego. Ponadto, jak zauważa polska etnolog, nie tylko budownictwo wiejskie, ale i cały system pracy na wsiach uzależniony jest od zmian zachodzących w przyrodzie. Podobnie też pozostająca z tym w łączności cała struktura życia społecznego i duchowego zachowała wiele archaicznych naleciałości, będących spadkiem po bardzo odległych epokach, tak jak to ma miejsce także w innych punktach wschodnich terenów Rzeczpospolitej ${ }^{58}$.

54 C. Baudouin de Courtenay-Ehrenkreutz, Kilka uwag i wiadomości o etnografii województwa wileńskiego, [w:] taż, Łańcuch tradycji..., s. 226.

55 Tamże, s. 278. Por.: K. Moszyński, Kultura ludowa Stowian, t. 2: Kultura duchowa, cz. 1-2, Warszawa 1968 , s. 589.

56 C. Baudouin de Courtenay-Ehrenkreutz, Kilka uwag i wiadomości..., s. 277-278.

57 Według autorki termin „cata” obejmuje wsie Pirciupie i Kukle (gm. kołtyniańska, pow. święciański). Tamże, s. 278. 
Kolejnym elementem, na który zwraca uwagę polska etnolog w badaniach ludności wiejskiej w województwie wileńskim, jest brak u ogromnej dotychczas większości jej przedstawicieli jasno skrystalizowanego poczucia narodowościowego ${ }^{59}$. Społeczeństwo chłopskie skupione jest przede wszystkim wokół Kościoła, stąd na podstawie głównie wyznaniowej wyrasta poczucie odrębności grupowej wśród ludności wiejskiej. Zdaniem autorki obserwuje się na tym terenie prymat dwóch Kościołów chrześcijańskich - katolickiego i prawosławnego. Jak pisze: Nie tylko bowiem ideologia religijna i formy kultów przedostają się do ludów wraz z obrządkiem, lecz wraz z tym i inne elementy cywilizacji, nadajace styl catemu nastawieniu życiowemu danego środowiska ${ }^{60}$.

Wyznanie przesadza też przede wszystkim o nastawieniu jej w kierunku tej lub innej narodowości warstw oświeconych, podczas gdy ani język domowy, ani inne wtaściwości w kulturze nie stanowia tu czynnika decydującego [...] Spotyka się chtopów zwróconych mitośnie ku ojcowiźnie, lecz jako ku ziemi karmicielce, dorobku ojców i dziadów, nie zaśku ojczyźnie w naszym tego stowa znaczeniu ${ }^{61}$.

Nie oznacza to jednak, że w społeczeństwie chłopskim nie trafiają się na tym terenie patrioci, a nawet całe rodziny, w których życie religijne, tradycja powstań narodowych są wciąż silne. Jak wynika z przeprowadzonych analiz, wśród ludności chłopskiej na badanym terenie świadomość narodowa jeszcze nie dojrzała. I chociaż występuje wśród ludności wiejskiej niekiedy przywiązanie do mowy ojczystej, nie przesądza ono o poczuciu jej odrębności narodowej.

Według Jędrzejewiczowej różnice pomiędzy ludnością wiejską wynikały z przynależności religijnej. Ludność objęta przez przeważający wpływ Kościoła katolickiego (asymilującego swych wiernych dla kultury polskiej, bez względu na używanie przez nią języka litewskiego czy białoruskiego) dzieliła przepaść od ludności białoruskiej, wciągniętej przez prawosławie w krąg moskiewskiego bizantynizmu. Oprócz tego do wyżej wymienionych nawarstwień w kulturze województwa wileńskiego dodać należałoby wpływ kultury północnogermańskiej (architektura), skandynawskiej (tkaniny, a także robione ze słomy sześcio- i ośmiościenne ${ }^{62}$ pająki zawieszane w chatach wiejskich), a także fińskiej ${ }^{63}$. Podobieństwa łączące województwo wileńskie ze światem fińskim polska uczona dostrzega np. w wytworach kultury materialnej. Świadczą o tym kształty

\footnotetext{
Zob. tamże, s. 330 .
}

60 Tamże, s. 336.

61 Tamże, s. 330.

62 Gdyż Jędrzejewiczowa zwraca uwagę na sześcio- i ośmiościenne pająki zawieszane w chatach wieśniaków w powiecie wileńsko-trockim znajdujące swych krewniaków również w Skandynawii. Pająki ze słomy zawieszano w woj. wileńskim u pułapu na Boże Narodzenie i na Wielkanoc, zwyczaj ten spotykany również na Półwyspie Skandynawskim. Szerzej na ten temat pisze ona w tekście "O etnicznych elementach w kulturze ludowej województwa” s. 339, [w:] Cezaria Baudouin de Courtenay-Ehrenkreutz-Jęrzejewiczowa, Eańcuch tradycji. Teksty wybrane, Warszawa 2005.

63 Pod względem wielu cech prawie identyczną z naszą kulturą rolną i pasterską - kulturę terenów łotewskich. Oprócz podobnych warunków przyrodniczych złożyło się na to wspólne etniczne podłoże bałtyckie oraz nawarstwienie białoruskie (pomijając inne elementy zbieżne kultury północnoeuropejskiej). 
naczyń plecionych i spajanych z łubu i kory, krój odzieży i sposób jej noszenia, a w kulturze duchowej i społecznej formy obrzędów, wierzenia i związane z nimi zwyczaje.

Szczególne miejsce w jej pracach zajmują tradycje obrzędowe, które uzewnętrzniają ważne społecznie przeżycia w sposób strukturalnie określony, wypracowany przez tradycję. Można z nich odczytać sposób tworzenia więzi społecznych i istotę rodzajów współżycia ludzi, którzy je praktykują. Zjawisko obrzędowości weselnej jako fakt historyczny ma swoją miejscową tradycję, która w literaturze etnograficznej doczekała się niewielu obszernych opracowann ${ }^{64}$. Pomijając różnice pomiędzy formami obrzędu weselnego u różnych etnicznie ludów europejskich, a interesując się podobieństwami, badacze - z wyjątkiem etnologów francuskich z Émilem Durkheimem na czele - nie brali pod uwagę istoty wytworów i wzajemnych zależności między cechami zewnętrznymi obrzędu a jego treścią wewnętrzną. Badania w tej dziedzinie nie obejmowały jednak terenów europejskich, koncentrowały się jedynie na badaniu obrzędowości u ludów pierwotnych ${ }^{65}$. Niektóre elementy obrzędu weselnego, obecnie występujące tylko na wschodniej rubieży terenów rdzennie polskich (np. w dawnym województwie wileńskim, nowogródzkim, białostockim), mogły istnieć także na ziemiach zachodnich, gdzie uległy jednak w znacznej mierze zaginięciu, wyparte przez nowe formy zwyczajowe.

Wesele od dawna - nie tylko w literaturze etnologicznej, lecz także w twórczości artystycznej i wyobraźni zbiorowej - funkcjonuje jako wzorcowy przykład święta, a zarazem niemal gotowy model ludzkiej aktywności dramaturgicznej. W odniesieniu do kultury ludowej w swojej pracy Forma dramatyczna obrzędowości weselnej (1929) Jędrzejewiczowa opisuje obrzędowość weselną jako zewnętrzny przejaw kształtowania się stosunków ustrojowych na terenach wschodniej Polski (w granicach sprzed 1939 r.), gdzie zachowały się pieśni i obrzędy weselne należące do starych tradycji ludowych. Polska etnolog traktuje formę dramatyczną obrzędu weselnego jako wynik określonych aktów intencjonalnych. Jej zdaniem istnieje jakiśs fakt rzeczywisty, ku któremu skierowany jest akt intencjonalny, wartościujący, i wreszcie mamy do czynienia z ukształtowaną i przekazaną przez tradycję formą, będącą uzewnętrznieniem zaistniałego aktu postrzegania w przeszłości. Materiał naukowy powinien być rozpatrywany metodą porównawczą opierającą się na badaniu form wytworów zróżnicowanych przede wszystkim przez teren, a nie przez czas. Pisząc o formie obrzędowości weselnej, Jędrzejewiczowa dowodzi, że jest wesele nie tylko „bajecznie kolorowym” widowiskiem i dramatem przebiegającym według określonego scenariusza, ale także - a nawet przede wszystkim - rozbudowanym aktem performatywnym, ustanawiającym relacje

64 Do ważniejszych badaczy piszących na temat obrzędów weselnych Słowian należą m.in. Kazimierz Moszyński (Kultura ludowa Stowian...); J.S. Bystroń (Etnografia Polski, Warszawa 1947); Zygmunt Gloger (Obchody weselne, Kraków 1869; Rok polski w życiu, tradycji i pieśni, Warszawa 1983); Michał Żmigrodzki (Lud Polski i Rusi. Wśród Stowian i Ariów, t. 1: Obrzędy weselne, Kraków 1907); Stanisław Pigoń (Na drogach kultury ludowej. Rozprawy i studia, wybór i oprac. T. Jodełka-Burzecki, Warszawa 1974).

65 Zagadnienie to opisał obszernie Bronisław Malinowski w książce Wierzenia pierwotne i formy ustroju spotecznego, Kraków 1915. 
międzyludzkie i tworzącym nową rzeczywistość: rodzinę ludzką. Oznacza to - jak wynika z systematycznie przeprowadzonej przez nią genezy wesela - że w jego przypadku przedstawienie jest przed prawem. Jest to o tyle istotne, iż współcześnie zwykliśmy myśleć, że wesele (a szerzej - każde przedstawienie) stanowi tylko swoisty dodatek do wypadku naturalnego, czynności sakralnej lub prawnej. Małżeństwo ustanawiane jest przez ślub - cywilny lub sakramentalny. Wesele - to zabawa, będąca wyrazem radości z tego faktu. Tak jest od niedawana. Jeszcze do końca XVI w. zaślubiny przeprowadzone zgodnie z tradycyjnym rytuałem były uznawane przez Kościół, a materiał zgromadzony przez Cezarię Jędrzejewiczową wyraźnie pokazuje, że jeszcze w XX w. na polskiej wsi wesele było podstawowym aktem tworzącym małżeństwo ${ }^{66}$. Prawo i sakrament dopiero w XX w. odniosły ostateczne zwycięstwo nad „najbardziej ludzkim” obrzędem rodzinnym ${ }^{67}$.

Analizy Jędrzejewiczowej świadczą o tym, iż zarówno kultura każdego środowiska, jak i jej najmniejszy element mają swój własny sens i jego uzasadnienie, jak też historię swego stawania się i kształtowania ${ }^{68}$. Powstanie tych zewnętrznych wyrazów zarówno obrzędów, jak i innych kategorii związanych np. z formalistyką prawną należy zawsze wiązać ze źródłami kształtowania się różnych form ustrojowych. W miarę krystalizowania się tych ostatnich jako wytworów zbiorowego bytowania ludzi zaczęty się równolegle urabiać i formy uwidaczniające dziatanie różnorodnych instytucji w sposób dla danych środowisk zrozumiaty, a zarazem stwierdzajace podporzadkowanie się im jednostek lub catych grup ${ }^{69}$. Gdy mamy do czynienia z pierwszymi organizacjami społecznymi związanymi z kultami zbiorowymi, jednocześnie widzimy, że wypowiadają się one w określonych formach zewnętrznych, gdzie za pośrednictwem znaków plastycznych i języka obrzędowego stają się uchwytne zarówno treść tych kultów, jak i stosunek do nich ich wyznawców ${ }^{70}$. Stosunek ten musiał znaleźć swoje uzewnętrznienie w określonych formach wyrażających akceptację lub potępienie. Formy mówiące o tym stosunku wykazują duże zróżnicowanie terytorialne, etniczne, są związane ponadto z ustrojem gospodarczym danej grupy. Zależą również od całości kultury, w której występują, od znaków plastycznych i zasobów językowych, jakimi dysponuje społeczeństwo. Ich istotą jednak jest to, że przede wszystkim sankcjonują pewne związki między ludźmi odmiennej płci, uznane jako związki małżeńskie. A więc formy zawarcia małżeństwa przejawiające się w formie obrzędowości weselnej są przetworzeniem pewnych faktów, są ich przeżyciem uzewnętrznionym w określony przez tradycję i ukształtowany przez szereg pokoleń sposób ${ }^{71}$. Ich zbadanie może zatem dać odpowiedź na pytanie

66 C. Baudouin de Courtenay-Ehrenkreutz-Jędrzejewiczowa, Ze studiów nad obrzędami weselnymi ludu polskiego, cz. 1: Forma dramatyczna obrzędowości weselnej, [w:] taż, Łańcuch tradycji..., s. 118-120.

Szerzej na ten temat zob.: D. Kosiński, Wesele - rzeczywistość ustanowiona, [w:] tenże, Teatra polskie historie, Warszawa 2010, s. 35.

68 C. Baudouin de Courtenay-Ehrenkreutz-Jędrzejewiczowa, Zaktad Etnologii Uniwersytetu Stefana Batorego w Wilnie i jego zadania, Wilno 1933, s. 22.

69 Tamże, s. 84 .

70 Zob.: tamże.

71 Zob.: taż, Ze studiów nad obrzędami..., s. 83. 
o kształtowanie się form ustrojowych współżycia grup ludzkich ${ }^{72}$. Przy czym nie chodzi o poszukiwanie historycznej zgodności faktów rozumianych jako wytwory kulturowe. Prawda w ujęciu Jędrzejewiczowej jest prawdą o istnieniu legendy, konstrukcji tej legendy jako zewnętrznej formy przeżycia określonych wydarzeń bez względu na to, jaki miały one przebieg. Prawda jest zatem wytworem kulturowym danej grupy ludzkiej, która ją przechowuje i przekazuje, jest reakcją tej grupy na szereg bodźców i wydarzeń zaistniałych w przeszłości. Jest wreszcie poszukiwaniem tego, co najistotniejsze w danym zjawisku - próbą dotarcia do struktury faktów dostępnych nam jako istotne wytwory kultury ludowej. Analiza formy dramatycznej obrzędowości weselnej, formy, która jest uzewnętrznieniem pewnych treści, podlegającej ewolucji, wykazuje mniej lub bardziej planowaną kompozycję, która zasadza się na porównaniu określonych zjawisk w aspekcie geograficznym. Traktując obrzęd jako tworzywo dramatyczne, autorka dąży do ustalenia jego stosunku do całokształtu struktury inscenizacyjnej. Obrzędy weselne mają na celu zademonstrowanie wobec społeczeństwa pewnych faktów (np. zawarcie małżeństwa). Inscenizacje tych faktów, czy wytworów ludzkich, odwołują się do starych tradycji obrzędowych i mają istotne znaczenie w kształtowaniu się wzajemnych relacji pomiędzy etnicznością a kulturą na danym terytorium.

4.

Problematyka etniczna, narodowościowa oraz związane z nią zagadnienia polityczno-państwowe ukazane zostały przez Cezarię Jędrzejewiczową na przykładzie Wielkiego Księstwa Litewskiego. Jedną z kluczowych prac poświęconych temu zagadnieniu jest powstały w późnym okresie tekst zatytułowany Grupy etniczne na ziemiach Wielkiego Księstwa Litewskiego i trzy narody (1953). Przeprowadzone przez autorkę analizy dowodzą, jak skomplikowany jest układ stosunków etniczno-narodowościowych na Litwie. Ich opisanie domagałoby się jeśli nie dogłębne analizy (na nią brak miejsca w skondensowanej treściowo formie artykułu) - to chociażby skrótowego nakreślenia przyczyn ich zaistnienia. Niedostrzeganie rzucających się w oczy procesów przemian językowych i kulturalnych jako składników osobowości etnicznej byłoby bagatelizowaniem rzeczy istotnych. By natomiast właściwie rozumieć zagadnienia etniczne i kulturowe na ziemiach byłego Księstwa Litewskiego, autorka wskazuje na wypowiedzi konkretnych osób i ich relacje, które rzucają pewne światło na cechy kultur etnicznych Litwy.

Istotne miejsce w terminologii Jędrzejewiczowej zajmują takie pojęcia, jak „lud” i „naród”. W tekście Grupy etniczne na ziemiach Wielkiego Księstwa Litewskiego i trzy narody czytamy: Lud i naród nie są pojęciami pokrywającymi się [...] Lud (franc. peuple, ang. Folk, niem. Volk) używany jest również dla określenia warstw chtopskich, i niektórych grup miejskich, w przeciwstawieniu do inteligenci (por. „tance ludowe” $i$,tańce narodowe").

72 Szerzej na ten temat zob.: A. Zadrożyńska-Barącz, Fenomenologiczna koncepcja..., s. 26. 
Sprawdzianem obiektywnym odrębności danego ludu jest przede wszystkim jezyk $k^{73}$.

Autorka zwraca uwagę na kontekstowy status obu pojęć. Jak pisze: Ziemie b[ytego] W[ielkiego] Ks[ięstwa] Litewskiego stanowity od wielu tysięcy lat terytorium, na jakim osiadaty, przez które wędrowaty i na jakim walczyty, zwyciężaty i ginęty różne grupy etniczne („szczepy”, „plemiona”, „ludy”) [...] Na kanwie pozostawionej przez nich tradycji - zwanej "podtożem” lub „substratem” - powstawaty kultury nowych ludów $w^{74}$.

Jak wynika z cytowanego tu fragmentu tekstu, żadna zbiorowość etniczna nie jest „etniczna” lub „nieetniczna” z własnej natury, ale wyłącznie w relacji do innej zbiorowości. Na przykład niektórzy Litwini uważają się za część narodu polskiego. Ich język oraz składniki kultury dowodzą jednak, że są odmiennym ludem i sami posiadają poczucie tej odrębności. Istotnie, obok ludności uprzednio litewskiej, lecz już językowo zrutenizowanej w wyniku przenikania języka administracji państwowej i warstw oświeconych, kształtowała się również na ziemiach Wielkiego Księstwa, na początku odgórnie, nowa grupa etniczna: rdzennych Litwinów porzucających swój własny język na rzecz języka polskiego. Był to proces trwający od kilku wieków, który spowodował zaistnienie na terytorium dawnej Rzeczpospolitej dwóch grup Polaków. Jedną grupę stanowili rdzenni Polacy, z początku jeńcy, osadzeni na ziemiach litewskich, następnie dobrowolnie osiadający przybysze z Polski, głównie z Mazowsza i Podlasia, żywioł miejski (rzemieślnicy, kupcy), dostojnicy dworscy, urzędnicy dóbr wielkoksiążęcych, duchowieństwo i innymi przedstawiciele warstw oświeconych. Drugą grupę tworzyli spolonizowani Litwini i rody językowo zbiałoruszczone, lecz pochodzenia litewskiego, które aż do II wojny światowej posiadały dokumenty nadania Wielkich Książąt Litewskich itp. pisane w staroruskim języku aktów urzędowych. W codziennym życiu, głównie dzięki Kościołowi i szkołom, wśród tej grupy ludności zwyciężał język polski, szerzony przez wyrażający go alfabet łaciński ${ }^{75}$. Od końca XVII w. polszczyzna stała się językiem urzędowym w Wielkim Księstwie Litewskim.

W definicji narodu za wyróżnik przyjmuje się więzi krwi (wiara w pochodzenie od wspólnego przodka) oraz kształtujące się na ich podłożu więzi kulturowe i psychiczne. Wyróżnikiem narodu jest też często wspólny język, kultura, wartości duchowe, symboliczne, a także posiadanie wspólnego terytorium (państwa) i instytucji służących realizacji określonych celów (np. sądownictwo). Niektórzy badacze podkreślają, iż kryterium językowe nie może być uważane za podstawowy wyróżnik narodu. Jest nim natomiast rodzaj kulturowej wspólnoty ${ }^{76}$. $\mathrm{Z}$ jednej strony istnieją bowiem narody nieposiadające własnego, odrębnego języka (np. Szwajcarzy), z drugiej zaś - istotny jest nie tyle fakt obecności odrębnego języka, ile jego funkcjonowanie w życiu codziennym.

\footnotetext{
73 C. Baudouin de Courtenay-Ehrenkreutz-Jędrzejewiczowa, Grupy etniczne na ziemiach Wielkiego Księstwa Litewskiego i trzy narody, [w:] taż, Eańcuch tradycji..., s. 365.

74 Tamże, s. 361.

75 Zob.: tamże, s. 368.

76 Na ten temat zob.: A. Kłoskowska, Kultury narodowe u korzeni, Warszawa 1996, s. 24.
} 
Można tu powołać się na przykład Białorusinów ${ }^{77}$, którzy wprawdzie posiadają własny język literacki, lecz w praktyce większość z nich posługuje się na co dzień językiem rosyjskim lub - w środowiskach wiejskich - gwarą $^{78}$.

Biorąc pod uwagę zadania współczesnej etnografii, Jędrzejewiczowa w swoich tekstach podkreśla rolę zbiorowej świadomości etnicznej. Jej zdaniem poznawanie tradycji grup etnicznych pogłębia poczucie świadomości narodowej nacjonalizujących się ludów. W krótkim tekście Dwie kultury i dwie nauki (1936) ${ }^{79}$ pisze: Jasnym jest, że w panstwach wzmacniajacych swe oblicze narodowe, w krajach pogtęiajacych swa zbiorowa świadomość etniczna "rasowa” kultura ludowa staje się najważiejszym źródtem odrodzenia ${ }^{80}$.

Badając kulturę ludową na terenie województwa wileńskiego (w granicach przed 1939 r.), próbuje dociec, gdzie w życiu grupy stoimy w obliczu więzi, którą moglibyśmy określić terminem „etnizm” (ethnicum), tj. więzi wyodrębniającej pewne grupy ludzkie spośród innych nie tylko na skutek działania czynników gospodarczych, lecz w wyniku innych procesów socjalnych i innych tradycji. Jak czytamy: Dzieje narodów i państw dowiodty, w ostatnich czasach jeszcze dobitniej, że jezyk nie zawsze $w$ tym zakresie stanowi czynnik decydujacy. Że natomiast istnieją inne więzi taczace ludzi w grupy, przede wszystkim zaśpewne wspólne kompleksy wytworów kultury ${ }^{81}$.

Polska etnolog wymienia dwa czynniki decydujące o dynamice przemian w kulturze. Pierwszym z nich jest opanowanie przyrody przez technikę, a drugim - pismo. W zależności od tego, czy społeczeństwo posługuje się pismem, czy nie, możemy podzielić kultury na dwie grupy: na kultury piśmienne, alfabetyczne, i na kultury analfabetyczne. Jak pisze: Inna bowiem dynamikę ksztattowania się wytworów, ich przekazywania, przemian i zaniku maja kultury piśmienne, inna - kultury nie znajace wyrażania sie przez pismo i szerzenia przez nie swych wytworów. Spoteczeństwa nieznające pisma wdrażają swych cztonków w tradycje kultury bezpośrednio, wpajając ustnie swe wiadomości oraz zaprawiając manipulacyjnie w swej umiejętności. Spoteczeństwa piśmienne przekazuja tylko pewna część swych tradycji bezpośrednio, wielkie jednak kompleksy wytworów przekazuja za pośrednictwem pisma, co się wtaśnie odbija na catej strukturze kultury. Szerzenie dorobku kultury za pomoca takiego systemu symbolicznego znaków jak pismo skraca czas podawania umiejętności w stosunku do tej ilości czasu, który musiatby być wtożony dla przekazania tej samej dozy wiadomości w sposób bezpośredni. Poza tym pismo nie tylko przedtuża pamięć ludzką o dziejach przesztych, lecz co najważniejsze - stwarza możność kontroli nad stowem ${ }^{82}$.

77 W 1926 r. 39,3\% mieszkańców miast określiło się jako Białorusini, a tylko 20\% spośród nich wskazało na białoruski jako język rodzimy. Natomiast wyniki spisu z 1989 r. wskazują, iż 80,22\% osób identyfikujących się jako Białorusini deklarowało jako rodzimy język białoruski. Zob. I. Kabzińska, Między grupq etniczna..., s. 53.

78 Zob.: tamże, s. 52.

79 Wykład wygłoszony 20 X 1934 r. na Uniwersytecie Józefa Piłsudzkiego (ob. Uniwersytet Warszawski).

80 C. Baudouin de Courtenay-Ehrenkreutz-Jędrzejewiczowa, Dwie kultury i dwie nauki, [w:] taż, Eańcuch tradycji..., s. 353.

81 Tamże, s. 354.

82 Tamże, s. 355. 
Tym samym - jak uzasadnia dalej autorka tekstu - tam, gdzie zaistniało pismo, tam narodziła się krytyka myśli, dająca zaczyn nauce, a więc i kulturze intelektualnej (umysłowej). Inaczej w kulturze analfabetycznej (manipulacyjnej), której przedstawiciele posługują się do wyrażania swych pomysłów konkretnym materiałem, którego lekkomyślne użycie (źle spleciony kosz lub źle zasiany łan zboża) grozi katastrofą (np. załamanie się kładki etc.). Dlatego też jej zdaniem współpraca etnografii (jako nauki badającej wytwory kultur drogą bezpośredniego kontaktu z grupą socjoetniczną, dążąc w ten sposób do poznania kultury danego środowiska, jej struktury oraz wartości i funkcji poszczególnych wytworów) z innymi naukami pozwoli zrozumieć całokształt cywilizacji ludzkiej i dynamikę jej wzrostów, przemian i rozkładów oraz pomoże wydobyć te działające w niej czynniki, wokół których krystalizuje się oblicze etniczne grupy i w związku z tym jej zbiorowa świadomość własnej odrębności etnicznej ${ }^{83}$.

W tekście Grupy etniczne na ziemiach Wielkiego Księstwa Litewskiego i trzy narody badaczka opisuje wspólny, stanowiący wypadkową współżycia różnych grup etnicznych (ludu polskiego, białoruskiego, litewskiego) zamieszkujących terytorium byłego Wielkiego Księstwa Litewskiego styl etniczny, charakteryzujący w ogóle wszystkich „tutejszych ludzi” ${ }^{4}$. Jędrzejewiczowa wychodzi z założenia, że nie ma czystych, niezmieszanych z innymi języków ani czystych kultur, gdyż nawet ludy pierwotne stykały się z innymi. Przy czym na im wyższym poziomie znajdują się język czy też kultura, tym bogatsze są one w obce naleciałości, przyswojone i przystosowane do własnego stylu cywilizacyjnego ${ }^{85}$. Tylko małe lub związane nikłą więzią tradycji zespoły etniczne, ludy i narody, względnie obarczone kompleksem niższości lub narody większe opętane manią wyższości tworzą mity o samorodności swej kultury.

Badania językoznawcze i kulturologiczne dziejów ludów Litwy przeprowadzone przez polską uczoną świadczą o skomplikowanych stosunkach etniczno-narodowościowych na Litwie ${ }^{86}$. Po pierwsze, granice pojęć narodu i grupy etnicznej na ziemiach byłego Wielkiego Księstwa Litewskiego nie pokrywają się, lecz tylko stykają w pewnych punktach. Wykazują nawarstwianie się, krzyżowanie i splatanie ze sobą cech, jednoczenie się, lecz i różnicowanie. $W$ rezultacie - jak pisze Jędrzejewiczowa wyrasta przed nami coś jeszcze, co nazwać możemy kultura Litwy, co nie jest jednak ani specjalnie litewskie, ani biatoruskie, ani polskie. Charakteryzuje natomiast ziemie bytego W. Księstwa Litewskiego, jako wypadkowa catoksztattu dziejów ${ }^{87}$. Po drugie, świadomość narodowa - solidaryzowanie się z tymi lub innymi tradycjami, czyli wola ludzi, tych istotnych podmiotów dziejów politycznych - łączy ludy w narody i drąży między nimi przepaście. Łączy w organizmy państwowe.

\footnotetext{
Zob.: tamże, s. 358.

84 Taż, Grupy etniczne..., s. 361.

85 Zob.: tamże, s. 362.
}

86 Dzieje nazwisk Polaków na Litwie świadczą o tym, jak skomplikowana była historia etniczna ich rodów. Toteż ani język, ani tradycje miejscowe, ani nawet wyznanie nie były czynnikiem rozstrzygającym o świadomości narodowej Polaków na Litwie.

87 C. Baudouin de Courtenay-Ehrenkreutz-Jędrzejewiczowa, Grupy etniczne..., s. 386. 
Za najbardziej miarodajne kryterium określające więzi etniczne uważa Jędrzejewiczowa język. Języki litewski, białoruski i polski należą do rodziny języków indoeuropejskich ${ }^{88}$. Na podstawie szeregu właściwości fonetycznych i morfologicznych większość jezykoznawców jest zdania, że istniał prawdopodobnie okres w dziejach przedhistorycznych przodków Litwinów i Słowian, kiedy stanowili oni jedną grupę etniczną, względnie jeden lud, mówiący wspólnym językiem ${ }^{89}$. Jeszcze szersze drogi rozpowszechniania treści kulturowych w przestrzeni i w czasie posiada drugie obok mowy narzędzie porozumiewania się, jakim jest pismo. Jak pisze Jędrzejewiczowa: Cyrylica szerzaca sięjako pierwsze pismo nie tylko wraz ze wschodnim obrządkiem, lecz z ośrodków dworskich i urzędów państwowych, wciagata ludność Litwy w krag panowania języka „ruskiego", nie tylko pisanego, lecz i mówionego ${ }^{90}$.

W rezultacie dokonującej się poprzez pismo slawizacji żywiołu litewskiego tworzyła się nowa grupa etniczna. Obok Białorusinów, z dawna osiadających na ziemiach litewskich, jak też ludności ruskiej powstała nowa grupa etniczna - Litwinów ${ }^{91}$, zarzucających swój własny język na rzecz języka państwowego, języka warstw oświeconych, staroruskiego, zarówno mówionego, jak i pisanego. $Z$ politycznego znaczenia języka (alfabetu, pisma) jako narzędzia zniewolenia - jak podkreśla uczona - zdawała sobie zawsze sprawę Rosja, zarówno carska, jak i sowiecka ${ }^{92}$. Inaczej wyglądało zagadnienie alfabetu w epoce chrztu Litwy. Chrzest Litwy w końcu XIV w. i związanie jej z kulturą zachodnią, a więc z alfabetem łacińskim, ocaliły od zagłady język litewski, cofający się wobec naporu języka staroruskiego. Jak podkreśla: Eaciński alfabet stanowit nie tylko pomost prowadzacy do zjednoczenia z kultura zachodnia, lecz i do polonizacji Litwinów ${ }^{93}$.

Istotny jest fakt, że na ziemiach byłego Księstwa Litewskiego dojrzewał język słowiański. Język stopniowo stający się językiem polskim. Język polski na ziemiach

88 Termin: języki indoeuropejskie (zwane w XIX wieku przez jego epigonów aryjskimi, a przez uczonych niemieckich - indogermańskimi) utworzono na podstawie następującej. Ludy mówiace nimi - pomijając kolonizacje przez nie w starożytności śródziemnomorskich wybrzeży Azji i Afryki, a z czasem Ameryki i Australii - wędrowaty i osiadty na przestrzeni między Indiami i europejskimi wybrzeżami Atlantyku, czyli sa językami Europy przede wszystkim z zasiegiem swym docierajacym $w$ Azji do Indiitaż, II. Pochodzenie grup etnicznych, ludów i narodów Litwy, [w:] taż, Eańcuch tradycji..., s. 387-388.

Zob.: tamize, s. 388 .

Tamże, s. 366.

91 Litwini są obecnie autochtoniczną społecznością północno-wschodniej części Polski, zamieszkującą w ok. 50 miejscowościach w gminach Puńsk i Sejny. Ich liczebność szacuje się na 6 do 20 tys. osób. Jest to społeczność charakteryzująca się wysokim stopniem świadomości narodowej, podtrzymywanej przez szkoły z litewskim językiem nauczania, organizacje kulturalnej i społeczne oraz Kościół. Litwini są w większości pochodzenia chłopskiego, stąd też tradycja ludowa jest dla nich niezwykle ważnym elementem podtrzymywania tożsamości narodowej. Wśród starszej generacji Litwinów niezwykle silna jest pamięć o dawnych obrzędach i zwyczajach związanych z kalendarzem świąt dorocznych i rodzinnych.

92 Zob.: C. Baudouin de Courtenay-Ehrenkreutz-Jędrzejewiczowa, II. Pochodzenie grup etnicznych..., s. 367. 
Wielkiego Księstwa Litewskiego ulegał istotnym przekształceniom w zależności od tego, czy nawarstwiał się na litewskie, czy też na białoruskie podłoże.

Do języków słowiańskich należą: język polski i język białoruski, łączy je więc bliższe pokrewieństwo niż z językiem litewskim, jednym z języków bałtyckich. Pomijając obszerne zagadnienie tworzenia się praojczyzny Słowian, Jędrzejewiczowa podkreśla, iż Wielkopolska była kolebką, w której nieprzerwanie od pierwocin kultury prasłowiańskiej kształtowała się polskośćć ${ }^{94}$ Bez względu zatem na dialektyczne odchylenia w polszczyźnie na Litwie podkreślić należy, iż w przeciwieństwie do języka litewskiego i języka białoruskiego, napisano na Litwie arcydzieła literatury polskiej. To właśnie poziom, jaki osiągnął język polski na ziemiach byłego Wielkiego Księstwa Litewskiego, świadczy o tym, jak wiele dały sobie nawzajem Polska i Litwa. Jednakże na ziemiach Litwy toczył się nieprzerwanie proces przemian etnicznych i proces przejmowania nowego języka, czy też zrywania z językiem przodków. Litwini zaczynali mówić i czytać po rusku lub też po polsku, przestając mówić po litewsku, a mieszkając na tej samej rodzimej ziemi. Polacy, litwinizując się językowo lub białorusinując - zrywali więzy z własnym językiem, zachowując inne cechy kultury. Polonizowali się Białorusini, przekazując również swym etnicznym spadkobiercom elementy kultury swych przodków. Jak zauważa polska etnolog: Mieszkańców ziem b. W. Księstwa Litewskiego, mówiących po biatorusku, dziela nie tylko dwa wyznania i różne treści kulturalne i tradycje historyczne, lecz że jezyk ich spetnia inna funkcje, niż jezyk litewski, zwierajacy w grupe etniczno-narodowa Litwinów. [...] Język biatoruski w terenie ma zasiegg daleko szerszy niż litewski ipolski w Litwie, lecz może wtaśnie stą wyptywają trudności związania go ze świadomościa narodowa ludu biatoruskiego $o^{95}$.

Język białoruski, jego geneza i historia związane są z grupą języków wschodniosłowiańskich, na którą składają się: język wielkorosyjski, białoruski i ukraiński. Język białoruski należy zatem do zespołu tych języków wschodniosłowiańskich, które w przeciwstawieniu do języka ukraińskiego tworzyły się na terenach północno-wschodnich kontynentu Europy, grawitujących ku Bałtykowi i jego północnym, lesistym pomorzom, oraz na ziemiach późniejszej Rosji centralnej, zamieszkałej poprzednio wyłącznie przez plemiona ugrofińskie ${ }^{96}$.

Polska etnolog charakteryzuje styl etniczny współczesnej kultury ziem byłego Księstwa Litewskiego, w którego obrębie zaznaczają się wpływy Litwinów, Białorusinów i Polaków. Strefy tych wpływów stanowią wykładnik dziejów politycznych - wykładnik walki i pokojowego współżycia. Badaczka podkreśla, iż kultura ludów na ziemiach byłego Wielkiego Księstwa jest w swym zasadniczym zrębie kulturą drewnianą (budownictwo, zdobnictwo, narzędzia pracy). Oś, wokół której koncentruje się życie gospodarcze, stanowi rolnictwo i chów bydła, odbijające się nie tylko w treściach i for-

94 Jan Baudouin de Courtenay nazywa jezyk polski „najbardziej stowiańskim”, ponieważ wtaśnie w jezyku tym zostaty posunięte najdalej procesy przemian, tkwiące od najstarszych czasów w języku prastowiańskim - tamże, s. 390.

95 Taż, Grupy etniczne..., s. 375.

96 Tamże, s. 390. 
mach zwyczajów dorocznych, lecz i w wierzeniach. Na kształtowanie się obrzędowości i obyczajów charakteryzujących kulturę Litwy wpływały rywalizujące ze sobą na jej terytorium dwa wyznania, wnoszące swoiste pierwiastki cywilizacyjne: katolicyzm i prawosławie. Żmudź związała się przez katolicyzm z Zachodem. Przez ziemię Auksztoty (tereny Litwy właściwej, etnicznej) przeszła od czasów przedhistorycznych linia ścierania się wpływów Wschodu walczących z wpływami Zachodu. Przenikające, również do czasów prehistorycznych, wpływy germańskie pozostawiły także ślady we współczesnej kulturze chłopskiej. Dotyczy to przede wszystkim słownictwa architektonicznego, co nasuwa przypuszczenia, że być może Gotowie uczyli tam budownictwa. Na wpływy germańskie wskazują także niektóre typy architektoniczne. Na przykład wygasające ostatnio domostwa - litewskie namasy - mieszczące w swym wnętrzu dom mieszkalny i inne zabudowania gospodarskie, czy litewskie karczmy, zwane stodołami (niemieckie Staddel $)^{97}$.

Właściwościami wyodrębniającymi czy też cechującymi kultury Białorusinów, Litwinów i Polaków są w dziedzinie architektury ludowej wpływy germańskie, szwedzkie. W zakresie kultury społecznej należy podkreślić, że wsie litewskie charakteryzuje silnie zaznaczający się patriarchalizm, ujmujący całokształt życia w wyraźnie zakreślone ramy, w przeciwieństwie do wsi białoruskich, które cechuje bardziej luźna struktura życia obyczajowego. Litwini szczycić się mogą pięknymi dainami, czyli pieśniami ${ }^{98}$. Wśród ludności prawosławnej jaskrawiej niż wśród ludności katolickiej zaznaczają się na ziemiach byłego Wielkiego Księstwa politeizm, jak i różne animistyczne wierzenia związane ze stosunkiem człowieka do przyrody, z jego powodzeniem i niepowodzeniem w życiu gospodarczym, splecione z kultem przodków. Na Żmudzi natknąć się można na niektóre elementy bardzo starych wpływów chrześcijańskich, jakie wyprzedziły oficjalne przyjęcie przez nią chrześcijaństwa. Należy do nich np. tak bardzo popularny tam kult św. Jerzego jako patrona rolnictwa ${ }^{99}$. Do kultu tego wielkiego świętego bizantyjskiego przyczynili się być może Wikingowie oraz Gotowie w pierwszych wiekach chrześcijaństwa. Dlatego też pieśni świętojerskie - zarówno teksty, jak i melodie - należą do najbardziej archaicznych zabytków przeszłości, a niektóre z nich wskazują wyraźnie na swe orientalne pochodzenie. Ujęcie to słusznie zwraca uwagę, że określone cechy kultury nabierają znaczenia etnicznego w określonych kontekstach. Toteż wzajemne relacje pomiędzy kulturą a etnicznością ostatecznie zdaje się określać praktyka społeczna i świadomość narodowa ${ }^{100}$. Współwystępowanie terminów „tożsamość etniczna” i „narodowa” odpowiada jednocześnie rzeczywistej sytuacji badanych przez Jędrzejewiczową zbiorowości. Część należących do niej osób reprezentuje bowiem typ

Szerzej na ten temat zob.: taż, II. Pochodzenie grup etnicznych..., s. 395.

98 Zbiór pieśni litewskich został zebrany w książce Melodje [!] ludowe litewskie, cz. 1, zebr. A. Juszkiewicz, oprac. O. Kolberg, I. Kopernicki, red. i wyd. Z. Noskowski, J. Baudouin de Courtenay, Kraków 1900.

99 Zob.: C. Baudouin de Courtenay-Ehrenkreutz-Jędrzejewiczowa, II. Pochodzenie grup etnicznych..., s. 397.

100 W literaturze funkcjonuje pojęcie państwa-narodu oraz narodu kulturowego. Terminu tego użyła np. Antonina Kłoskowska, która podkreśla, iż naród - w przeciwieństwie do państwa - jest zbiorem spotecznym o charakterze kulturowej wspólnoty - taż, Kultury narodowe..., s. 24. 
tożsamości narodowej, charakteryzuje się świadomym uczestnictwem w narodowym dziedzictwie, w niektórych przypadkach natomiast można mówić o tożsamości etnicznej, tj. o identyfikacji z grupą „swoich”, z lokalnym terytorium, uczestnictwie w cząstce kultury polskiej, utożsamianej najczęściej z religią rzymskokatolicką i funkcjonowaniem tzw. „polskiego Kościoła"101.

Zbiór tekstów zatytułowanych Łańcuch tradycji (2005) zawiera bogaty materiał, będący wynikiem rozmów autorki z mieszkańcami ziem byłego Księstwa Litewskiego. Teksty te ujawniają istniejące na tym terenie silne więzi etniczne i kulturowe. Jak czytamy: Polski wyraz naród - spokrewniony etymologicznie, podobnie jak się rzecz ma we wszystkich jezykach stowiańskich, z wyrazem: ród, rodzić, rodzice, narodzenie - używany jest w dwóch znaczeniach. W jezyku ludowym, jak to sama niejednokrotnie stwierdzićmogtam, oznacza nieokreślona blizej gromadę ludzi $i^{102}$.

Jak wynika z przywołanego fragmentu tekstu, u ludności wiejskiej obserwuje się brak poczucia przynależności narodowej, w przeciwieństwie do istniejących na terenie byłej Rzeczpospolitej silnych więzi: wyznania, języka, kultury oraz istnienie takich faktów, jak przekazywana przez pokolenia tradycja obrzędowa.

Podsumowując, warto podkreślić, że - jak wykazały przywołane tu składniki kultury, które uważamy za swoje, o ile chcemy, aby nimi były - genetycznie nie stanowią one więzi etnicznej, świadczą raczej o łączności z innymi ludźmi, krajami bądź też o daleko idących w kulturze analogiach. Prace polskiej uczonej dowodzą, iż by tak powiedzieć, etniczna „polskość” ma mniejsze znaczenie wobec funkcjonalnej skuteczności. „Polskie” oznacza nie genetycznie „nasze”, „swojskie”, lecz wybierane przez zbiorowość i skutecznie wykorzystywane sposoby budowania i przekazywania wiedzy o sobie. Natomiast fenomenologiczne spojrzenie na wytwory i praktyki ludu polskiego mogłoby stać się uzupełnieniem stosowanych obecnie metod badawczych. Na przykład rozwijanej dziś ekologii performatywnej, zapoczątkowanej przez Mieczysława Limanowskiego, który w słynnym eseju Rok polski i dusza zbiorowa ${ }^{103}$, opublikowanym po raz pierwszy w Moskwie w 1916 r., wprowadził do świata przedstawień i teatru termin „rok polski” ${ }^{04}$. W tej perspektywie prace Jędrzejewiczowej poświęcone zagadnieniom języka, zwyczajom i obrzędowości weselnej są nadal aktualne. Teksty mówiące o etnografii województwa wileńskiego i grupach etnicznych na tych ziemiach należy traktować raczej jako dokument rozwoju myśli naukowej.

101 Zob.: I. Kabzińska, Między grupa etniczną..., s. 57.

102 C. Baudouin de Courtenay-Ehrenkreutz-Jędrzejewiczowa, Grupy etniczne..., s. 369.

103 Zob.: M. Limanowski, Rok polski i dusza zbiorowa, [w:] tenże, Byt kiedyśteatr Dionizosa, wstęp, wybór i oprac. Z. Osiński, Warszawa 1994.

104 Rok polski jest pierwszym dramatem i pierwszą kompozycją tworzącą ramy dla wielu polskich przedstawień świątecznych i codziennych. Od 1900 r., czyli od wydania książki Zygmunta Glogera Rok polski w życiu, tradycji i pieśni, pojęciem tym określa się cykliczny układ polskich świąt i obchodów tworzących rok obrzędowy i zwyczajowy. Szerzej na ten temat zob.: D. Kosiński, Misterium roku polskiego, „Dialog” 2007, nr 7/8, s. 188-204. 


\section{BIBLIOGRAFIA}

Archiwum Akt Nowych w Warszawie, Ministerstwo Wyznań Religijnych i Oświecenia Publicznego, j.3142.

Archiwum Polskiej Akademii Nauk w Warszawie, Materiały Cezarii Baudouin de Courtenay-Ehrenkreutz-Jędrzejewiczowej, sygn. 31.

Archiwum Polskiej Akademii Nauk w Warszawie, Materiały Rodziny Baudouin de Courtenay, sygn. III-298.

Babiński G., Pogranicze polsko-ukraińskie. Etnicznosś, zróżnicowanie religijne, tożsamość, Kraków 1997.

Barth F., Introducion, [w:] Ethnic Groups and Boundaries. The Social Organisation of Cultural Difference, red. tenże, Boston 1969.

Baudouin de Courtenay-Ehrenkreutz-Jędrzejewiczowa C., Eańcuch tradycji. Teksty wybrane, wybór L. Mróz, A. Zadrożyńska, Warszawa 2005, Archiwum Etnologiczne.

Baudouin de Courtenay-Ehrenkreutz-Jędrzejewiczowa C., Zaktad Etnologii Uniwersytetu Stefana Batorego w Wilnie i jego zadania, Wilno 1933.

Byta taka szkota. Gimnazjum im. Elizy Orzeszkowej w Wilnie, 1915-1939, red. E. Sławińska-Zokościelna, Londyn 1987.

Bystron J.S., Etnografia Polski, Warszawa 1947.

Bystroń J.S., Wstęp do ludoznawstwa polskiego, Lwów 1926, Lwowska Biblioteka Slawistycz$n a, 1$.

Dégh L., The Study of Ethnicity in Modern European Ethnology, [w:] Folklore, Nationalism and Politics, red. F.J. Oinas, Columbus 1978, Indiana University Folklore Institute Monograph Series.

Draus J., Oświata i nauka polska na Bliskim i Środkowym Wschodzie 1939-1950, Lublin 1993, Źródta i Monografie Towarzystwa Naukowego Katolickiego Uniwersytetu Lubelskiego, 124.

Draus J., Życie i dziatalność Cezarii Baudouin de Courtenay-Ehrenkreutz-Jędrzejewiczowej (1885-1967), [w:] Losy Polek żyjących na obczyźnie i ich wktad w kulturę i naukęświata - bistoria i wspótczesność. Materiaty z IV Sympozjum Biografistyki Polonijnej - Wiedeń 1-2 września 1999, red. A. Judycka, Z. Judycki, Lublin 1999.

Draus J., Terlecki R., Polskie szkoty wyższe i instytucje naukowe na emigracji 1939-1945, Wrocław 1984, Nauka dla Wszystkich, 382.

Dubicki T., Polscy uchodżcy w Rumunii 1939-1945. Studia i materiaty, Warszawa 1995.

Etnografowie i ludoznawcy polscy. Sylwetki, szkice biograficzne, t. 1, red. E. Fryś-Pietraszkowa, A. Kowalska-Lewicka, A. Spiss, Kraków 2002.

Gawenda J., Jej zycie to walka o wolnq naukę i kulture polska, [w:] M. Ehrenkreutz-Jasińska, Romualda i Cezaria. Konkurs „Prababka w kolorze sepii”, „Twój Styl” 1993, nr 7/8.

Gloger Z., Obchody weselne, Kraków 1869.

Gloger Z., Rok polski w życiu, tradycji i pieśni, Warszawa 1983.

Historia etnografii polskiej, red. M. Terlecka, Wrocław 1973, Historia Nauk Spotecznych i Humanistycznych w Polsce.

Jackiewicz M., Nauka i uczeni na ziemi wileńskiej od XVI w. do 1945 r., Bydgoszcz 2010, Biblioteka Wileńskich Rozmaitości. Seria B, 74. Encyklopedia Ziemi Wileńskiej, 9. 
Jasiewicz Z., Polacy z Ukrainy w Kazachstanie. Etniczność i historia, „Lud” 1992, t. 75.

Jasiewicz Z., Tatarzy polscy. Grupa etniczna czy etnograficzna?, „Lud” 1980, t. 64.

Judycki Z.A., Polski Uniwersytet na Obczyźnie w Londynie. Stownik biograficzny pracowników naukowych, Londyn 2008.

Kabzińska I., Między grupq etnicznq̨ a narodem, „Etnografia Polska” 2000, t. 44, z. 1-2.

Kłoskowska A., Kultury narodowe u korzeni, Warszawa 1996.

Kopczyńska-Jaworska B., Problem świadomości etnicznej i narodowej. Metody i osiagnięcia badań polskiej etnografii, „Lud” 1983, t. 67.

Kosiński D., Misterium roku polskiego, „Dialog” 2007, nr 7/8.

Kosiński D., Teatra polskie - historie, Warszawa 2010.

Limanowski M., Byt kiedyś teatr Dionizosa, wstęp, wybór i oprac. Z. Osiński, Warszawa 1994.

Malinowski B., Wierzenia pierwotne i formy ustroju spotecznego, Kraków 1915.

Melodje [!] ludowe litewskie, cz. 1, zebr. A. Juszkiewicz, oprac. O. Kolberg, I. Kopernicki, red.

i wyd. Z. Noskowski, J. Baudouin de Courtenay, Kraków 1900.

Michna E., Eemkowie. Grupa etniczna czy naród?, Kraków 1995, Religiologica Juventa.

Moszyński K., Cztowiek. Wstęp do etnografii powszechnej i etnologii, Wrocław 1958.

Moszyński K., Kultura ludowa Stowian, t. 2: Kultura duchowa, cz. 1-2, Warszawa 1968.

Obrębski J., Problem etniczny Polesia, „Sprawy Narodowościowe” 1936, R. 10, nr 1-2.

Obrębski J., Problem grup etnicznych w etnologii i jego socjologiczne ujęcie, „Przegląd Socjologiczny" 1936, t. 4.

Pastuszka W., Muzeum Etnograficzne Uniwersytetu Stefana Batorego w Wilnie. Prośba o pomoc, Archeowieści, 5 III 2013, [online] http://archeowiesci.pl/2013/03/05/muzeum-etnograficzne-uniwersytetu-stefana-batorego-w-wilnie-prosba-o-pomoc/.

Pigoń S., Na drogach kultury ludowej. Rozprawy i studia, wybór i oprac. T. Jodełka-Burzecki, Warszawa 1974.

Polski Uniwersytet na Obczyźnie w Londynie, [online] http://www.puno.edu.pl.

Posern-Zieliński A., III. Problematyka etniczna $w$ badaniach etnologicznych $i$ antropologicznych. Studia etniczne w polskiej etnologii po 1945 roku. Ich uwarunkowania, konteksty i nurty, „Lud” 1995, t. 78.

Róziewicz J., Powiązanie Jana Niecistawa Baudouin z petersburskim ośrodkiem naukowym, [w:] Dziatalność naukowa, dydaktyczna i spoteczno-polityczna Jana Niecistawa Baudouina de Courtenay w Rosji, red. tenże, Wrocław 1991.

Sadowski A., Narody wielkie i mate - Biatorusini w Polsce, Kraków 1991.

Sadowski A., Pogranicze polsko-biatoruskie. Tożsamość mieszkańców, Białystok 1995.

Sulimirski T., Fundusz Kultury Narodowej 1939-1946, „Nauka Polska na Obczyźnie” (Londyn) 1961, z. 3.

Szczepański M.S., Region pogranicza kulturowego w perspektywie socjologicznej. Przypadek Górnego Ślaska, [w:] Kultury regionalne i pogranicza kulturowe a świadomość etniczna, red. I. Bukowska-Floreńska, Katowice 1999, Prace Naukowe Uniwersytetu Śląkiego w Katowicach, 1749. Studia Etnologiczne i Antropologiczne, 2.

Szynkiewicz S., Silva ethnicum, [w:] Konflikty etniczne. Źródta, typy, sposoby rozstrzygania, red.

I. Kabzińska-Stawarz, S. Szynkiewicz, Warszawa 1996, Biblioteka Etnografii Polskiej, 51.

Śródka A., Uczeni polscy XIX-XX stulecia, t. 1: A-G, Warszawa 1994. 
Turkowski L., Prof. dr Cezaria Baudouin de Courtenay-Ehrenkreutz-Jędrzejewiczowa. Wspomnienie, „Lud” 1968, t. 52.

Zadrożyńska-Barącz A., Fenomenologiczna koncepcja historii $i$ kultury. Zastosowanie w polskich badaniach etnograficznych, „Etnografia Polska” 1968, t. 12.

Zamojska D., Cezaria Baudouin de Courtenay-Ehrenkreutz-Jędrzejewiczowa, [w:] Kobieta $i$ kultura. Kobiety wśród twórców kultury intelektualnej $i$ artystycznej $w$ dobie rozbiorów i $w$ niepodlegtym państwie polskim. Zbiór studiów, t. 4, red. A. Żarnowska, A. Szwarc, Warszawa 1996.

Żmigrodzki M., Lud Polski i Rusi. Wśród Stowian i Ariów, t. 1: Obrzędy weselne, Kraków 1907.

Dr Lilianna DORAK-WOJAKOWSKA - adiunkt w Instytucie Kulturoznawstwa Akademii Ignatianum w Krakowie, absolwentka teatrologii Uniwersytetu Jagiellońskiego. Jej zainteresowania naukowe koncentrują się wokół problematyki związków teatru i antropologii kultury. Główny nurt jej badań obejmuje poszukiwanie elementów wspólnych dla form teatralnych i parateatralnych powstałych w różnych tradycjach kulturowych. Autorka książki Poetyka cielesności w utworach dramatycznych Tadeusza Różewicza. Publikuje m.in. w „Perspektywach Kultury”, „Horyzontach Wychowania”, pracach zbiorowych: Teatr, przestrzeń, ciato, dialog. Poszukiwania we wspótczesnym teatrze; Zwrot performatywny w estetyce oraz seriach wydawniczych: Dramat Wspótczesny. Interpretacje; Humanitas. Studia Kulturoznawcze; Varia Culturalia oraz tomie Etos życia - etos sztuki. Wokót legendy o św. Genezjuszu - aktorze. 